\title{
43. TIMING OF ORE DEPOSITION AND SILL INTRUSION AT SITE 856: EVIDENCE FROM STRATIGRAPHY, ALTERATION, AND SEDIMENT PORE-WATER COMPOSITION ${ }^{1}$
}

\author{
Michael J. Mottl, ${ }^{2}$ C. Geoffrey Wheat, ${ }^{2}$ and J. Boulegue ${ }^{3}$
}

\begin{abstract}
A major objective of drilling at Site 856 was to determine the relationship, if any, between the large massive sulfide deposit there and the adjacent small, circular hill called Bent Hill. Bent Hill, like several nearby hills, is cored by a bright seismic reflector inferred to be an intrusion, probably consisting of sills similar to the three penetrated in Holes 856A and 856B. These intrusions are believed to have uplifted the hills. Stratigraphic relationships and other evidence suggest that the massive sulfide body began to form in the Pleistocene, whereas Bent Hill was uplifted in the Holocene. The deposit is therefore not genetically related to the hill. Hole 856B on the flank of Bent Hill penetrated several beds of clastic massive sulfide that probably slumped from the adjacent deposit. The thickness of Pleistocene sediment deposited on top of these beds implies that massive sulfide had already begun to form by 140,000 to $220,000 \mathrm{yr}$ ago. Whereas the sulfide body contains virtually no sedimentary interbeds and is presently exposed at the seafloor, Bent Hill is covered by up to $1 \mathrm{~m}$ of Holocene hemipelagic sediment that was probably deposited prior to uplift of the hill.

Most of the alteration of the sediments at Site 856 occurred within the hydrothermal upflow zone that formed the massive sulfide deposit. However, a late episode of high-temperature alteration affected the Pleistocene sediments at Site 856 that overlie the beds of clastic massive sulfide in Hole 856B. This alteration may have resulted from intrusion of the sills that uplifted the hill. Heating by the three sills penetrated in Holes $856 \mathrm{~A}$ and $856 \mathrm{~B}$ caused anhydrite to precipitate in the sediment; this anhydrite is presently dissolving. Sediment pore waters at Site 856 resemble bottom seawater more than at the other sites, indicating that they have reacted less with the sediment even though they are warmer than waters at Sites 855 and 857 over the same depth interval. The chlorinity of Site 856 pore waters is nearly identical with that of present-day bottom seawater. The absence of more saline Pleistocene bottom water indicates that the sediment column at Site 856 has been flushed with bottom seawater within the past few thousand years, probably by circulation that accompanied sill intrusion and the uplift of Bent Hill. However, uplift and slumping of sediment from the flank of the hill at Hole $856 \mathrm{~B}$ occurred long enough ago to produce relatively mature profiles of dissolved sulfate, ammonium, and calcium within the upper 20 mbsf.
\end{abstract}

\section{INTRODUCTION}

Middle Valley is a sediment-filled rift that until recently was the primary axis of seafloor spreading at the northern end of the Juan de Fuca Ridge (Fig. 1). During the Middle Brunhes Epoch, less than $200,000 \mathrm{yr}$ ago and probably within the last 10,000 to $15,000 \mathrm{yr}$, spreading jumped westward from Middle Valley to West Valley (Karsten et al., 1986; Davis and Villinger, 1992). Middle Valley is filled to a depth of more than $2 \mathrm{~km}$ in places with turbidite sediment shed from the North American continental margin during the Pleistocene glaciation. The young age of the crust, which is probably nowhere more than $400,000 \mathrm{yr}$ old, and the thick sediment cover combine to produce high temperatures and accompanying hydrothermal circulation within the sediment and shallow basement.

Middle Valley is highly asymmetrical. The western two-thirds is a deep rift that contains the thickest sediment, especially toward the north, while the eastern third overlies a basement bench that is covered by only a few hundred meters of sediment. This bench is a fault block that lies between two west-facing normal faults. One of these faults bounds the deep central rift on its eastern edge, while the other is the easternmost bounding fault of Middle Valley. Rohr and Schmidt (this volume) have interpreted the basement of this fault block to consist of a sediment-sill complex that appears as nearly flat, highamplitude reflectors that begin 200 to 500 milliseconds (ms) below the seafloor. These reflectors are 100 to $500 \mathrm{~m}$ wide and are elongate parallel to the strike of the valley, suggesting that the sills originate from extensional faults.

\footnotetext{
${ }^{1}$ Mottl, M.J., Davis, E.E., Fisher, A.T., and Slack, J.F. (Eds.), 1994. Proc. ODP. Sci. Results, 139: College Station, TX (Ocean Drilling Program).

${ }^{2}$ Department of Oceanography, School of Ocean and Earth Science and Technology, University of Hawaii, 1000 Pope Road, Honolulu, HI 96822, U.S.A.

${ }^{3}$ Laboratoire de Geochimie, Université Pierre et Marie Curie, 4 Place Jussieu, 75252 Paris Cedex 05, France.
}

Within the eastern third of Middle Valley there are numerous small, circular hills. These hills are typically several hundred meters across and rise several tens of meters above the smooth valley floor (Fig. 1). The hills are oriented approximately north-northeast, parallel to the eastern boundary fault of the valley. Seismic profiles show these hills to be constructed of uplifted sediment and cored by bright reflectors typically 100 to $150 \mathrm{~ms}$ below their surfaces, that are considerably smaller along strike than the sills that floor the sedimentary section. These reflectors are thought to be buried lava flows, sills, or plugshaped laccoliths. Davis and Villinger (1992) assumed that the hills were uplifted by intrusion of these associated sills or laccoliths. The hills are nonetheless thermally extinct, based on heat flow data. As some of the sills were intruded high into the sediment column, in some cases within $25 \mathrm{~m}$ below seafloor (mbsf), Davis and Villinger inferred that the hills cannot be more than a few tens of thousands of years old. On the other hand, they suggested from the lack of a thermal anomaly that the hills are at least a few thousand years old, as this much time would be required to dissipate the heat of intrusion.

These hills are of interest because they commonly are associated with massive sulfide deposits, both in Middle Valley (Davis et al., 1987; Goodfellow and Blaise, 1988) and in other sedimented rifts, including Guaymas Basin in the Gulf of California (Lawver and Williams, 1979; Lonsdale and Becker, 1985) and Escanaba Trough on the Gorda Ridge (Morton et al., 1987; Zierenberg et al., in press). The genetic relationship between the hills and the sulfide mineralization is not well understood. Site 856 in Middle Valley was drilled in part to investigate this relationship. In this paper we summarize evidence that the massive sulfide deposit at Site 856 is not genetically related to the hill there, which appears to be younger than the deposit. In particular, we use profiles of sediment pore-water composition from Holes $856 \mathrm{~A}$ and $856 \mathrm{~B}$, drilled into the hill just north of the sulfide deposit, to suggest that the hill formed quite recently, in the Holocene, by uplift of turbidite sediment above sub- or intrasedimentary igneous intrusions, whereas the deposit is probably mainly Pleistocene in age. 


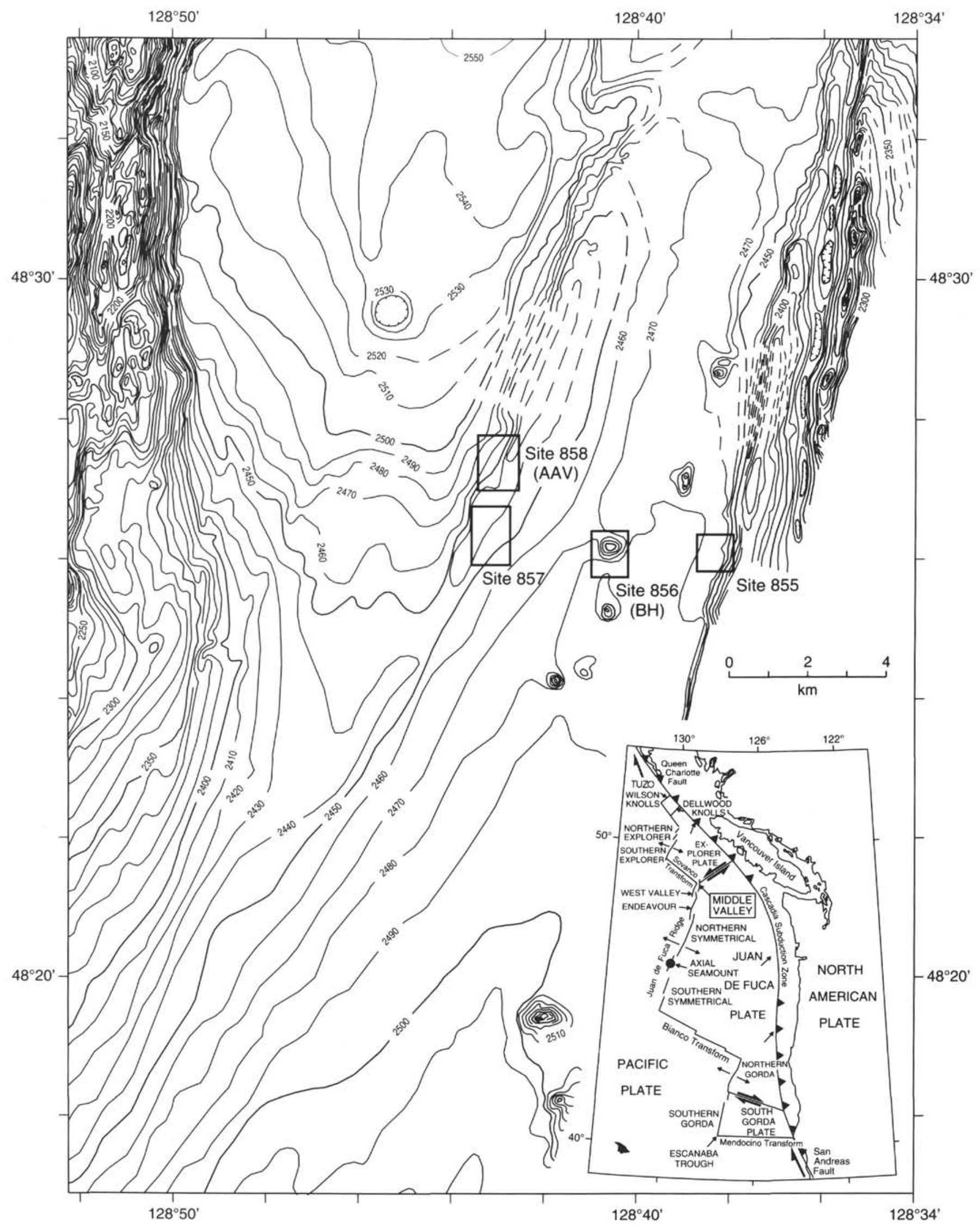

Figure 1. Location and bathymetric map of Middle Valley, showing the Leg 139 drill sites. Bathymetry in meters. 


\section{GEOLOGIC SETTING}

Site 856 is located in the southeastern part of Middle Valley, about $3 \mathrm{~km}$ west of the eastern boundary fault and $4 \mathrm{~km}$ east of the eastern fault that bounds the deep central rift axis of the valley (Fig. 1). The crust there could be as old as $320,000 \mathrm{yr}$, based on its distance from the eastern Brunhes magnetic chron (Davis and Villinger, 1992). The features targeted for drilling at the site are a circular hill, called Bent Hill, and a massive sulfide deposit that outcrops only $50 \mathrm{~m}$ to the south (Fig. 2). Although neither of these features is thermally active at present, there is a small mound of sulfide rubble another $300 \mathrm{~m}$ to the south that was not drilled, from which hot water is venting at $265^{\circ} \mathrm{C}$. Holes $856 \mathrm{~A}$ and $856 \mathrm{~B}$ were drilled into the hill, which is circular in plan view, about $500 \mathrm{~m}$ in diameter, and $60 \mathrm{~m}$ high. The hill has a flat, smooth top, but its perimeter is incised by erosional rills that expose slightly indurated sediment in outcrop. The western flank is steep, linear, and probably fault-controlled. The bright seismic reflector beneath this hill lies at a sub-bottom two-way traveltime of 170 $\mathrm{ms}$, while the depth to acoustic basement in the surrounding region is 400 to $500 \mathrm{~ms}$, or about 350 to 450 mbsf (Shipboard Scientific Party, 1992). Six holes were drilled into the large massive sulfide deposit, which forms a $30-\mathrm{m}$-high east-west ridge. The deepest of these holes penetrated $94 \mathrm{~m}$ into the deposit without reaching its base.

Hole 856A was drilled on the summit of Bent Hill. Hole 856B was drilled $190 \mathrm{~m}$ to the south, on the flank of Bent Hill, at a location 25 $\mathrm{m}$ deeper than the summit. Both holes penetrated turbidite sediment that has been hydrothermally altered, followed by basaltic rock at depths of 112 and $120 \mathrm{mbsf}$, respectively, interpreted to be the top of thick sills. Hole $856 \mathrm{~B}$ also intersected a sill less than $6 \mathrm{~m}$ thick at 62 mbsf, and a zone of clastic sulfide sediment at 18 to 24 mbsf.

\section{STRATIGRAPHY AND ALTERATION}

The only primary stratigraphic boundary in the sediment at Site 856 is that between Holocene hemipelagic silty clay at $0-1$ mbsf in Hole $856 \mathrm{~A}$ only, and Pleistocene turbidite at greater depth. The Holocene strata are absent in Hole 856B (Brunner, this volume), presumably because they have been lost by slumping, as indicated by magnetostratigraphic correlation between the two holes, which suggests that $21 \mathrm{~m}$ of sediment is missing from the top of Hole 856B (Shipboard Scientific Party, 1992). Lithostratigraphic boundaries are therefore largely defined on the basis of alteration. Table 1 compares the units defined by the Shipboard Scientific Party (1992) with those of Leybourne and Goodfellow (this volume), which are based on shore-based studies of alteration mineral assemblages. Although alteration increases with depth in both Holes $856 \mathrm{~A}$ and $856 \mathrm{~B}$, it is much more intense in Hole $856 \mathrm{~B}$, which is closer to the adjacent massive sulfide deposit. The most altered unit, shipboard Unit IID, which corresponds to Units I and II of Leybourne and Goodfellow, occurs only in Hole 856B.

Also restricted to Hole $856 \mathrm{~B}$ is Unit IIB, which comprises three intervals and is distinguished by highly variable directions of dip, implying rotation. The upper and lower intervals consist of interbedded hemipelagic and turbiditic sediment of Pleistocene age. The 6-m-thick middle interval includes these same materials, interbedded with at least 10 graded sequences up to $20 \mathrm{~cm}$ thick of variably weathered, oxidized clasts of massive sulfide sediment, mostly pyrite. The clasts are generally mud- to sand-size, but range up to $2.5 \mathrm{~cm}$. The entire unit has been interpreted as either a slump deposit or an in-situ rotated block, although the possibility that the rotation originated as drilling disturbance could not be ruled out. Goodfellow and Franklin (in press) have recovered similar clastic sulfide interbeds in shallow cores on the margins of the massive sulfide body, from sediment as young as Holocene. Some of the sulfide minerals in these clastic sulfide interbeds appear fresh and unoxidized, suggesting that not only the slump deposits but the sulfides that compose them may have formed within the Holocene.
Table 1. Lithostratigraphic units at Site 856.

\begin{tabular}{|c|c|c|c|}
\hline \multirow[b]{2}{*}{ Unit $^{\mathrm{a}}$} & \multirow[b]{2}{*}{ Description } & \multicolumn{2}{|c|}{ Depth (mbsf) } \\
\hline & & Hole $856 \mathrm{~A}$ & Hole $856 \mathrm{~B}$ \\
\hline $\begin{array}{l}\text { Holocene: } \\
\text { I }\end{array}$ & Hemipelagic silty clay & $0-1$ & none \\
\hline $\begin{array}{l}\text { Pleistocene: } \\
\text { IIA }\end{array}$ & $\begin{array}{l}\text { Weakly altered hemipelagic sediment and } \\
\text { turbidite }\end{array}$ & $1-86$ & $\begin{array}{r}0-12 \\
28-40\end{array}$ \\
\hline (IV) & Calcite-smectite-pyrite & $16-86$ & none \\
\hline IIB & $\begin{array}{l}\text { Slumped(?) hemipelagic, turbiditic, and } \\
\text { clastic sulfide sediment }\end{array}$ & $\begin{array}{l}\text { none } \\
\text { none }\end{array}$ & $\begin{array}{l}12-28 \\
18-24\end{array}$ \\
\hline ПС & $\begin{array}{l}\text { Moderately altered, indurated hemipelagic } \\
\text { sediment and turbidite with crystal molds } \\
\text { and brecciation }\end{array}$ & $86-113$ & $\begin{array}{l}40-62 \\
63-71\end{array}$ \\
\hline (III) & Anhydrite-smectite-pyrite-barite & $86-113$ & $28-71$ \\
\hline IID & $\begin{array}{l}\text { Moderately to well indurated hemipelagic } \\
\text { and turbiditic sediment with downward } \\
\text { increasing sulfide mineralization }\end{array}$ & none & $71-120$ \\
\hline (II) & Albite-chlorite-pyrite & none & $71-110$ \\
\hline$(1-1)$ & $\begin{array}{l}\text { Quartz-muscovite-Fe chlorite-rutile- } \\
\text { pyrrhotite-chalcopyrite }\end{array}$ & none & $110-117$ \\
\hline$(\mathrm{I}-2)$ & Quartz-chlorite-pyrite & none & $117-120$ \\
\hline
\end{tabular}

${ }^{a}$ Units are those defined by the Shipboard Scientific Party (1992). Units in parentheses are the alteration mineral zones defined by Leyboume and Goodfellow (this volume).

The Shipboard Scientific Party (1992) and Leybourne and Goodfellow (this volume) inferred that most of the alteration in Holes $856 \mathrm{~A}$ and $856 \mathrm{~B}$ took place within the hydrothermal upflow zone that formed the massive sulfide deposit (Fig. 3). By comparison, the alteration produced by intrusion of the three sills that were intersected by drilling was considered to be local and minimal. Increased induration, alteration, brecciation, and fracturing were observed within Unit IIC in both holes, but these effects extend only about $25 \mathrm{~m}$ above the basal sill in Hole $856 \mathrm{~A}$, and $25 \mathrm{~m}$ above and $10 \mathrm{~m}$ below the mid-level sill in Hole $856 \mathrm{~B}$. The pervasively intense alteration of Unit IID masks any effect of intrusion of the basal sill in Hole 856B.

An important feature of the alteration in Holes $856 \mathrm{~A}$ and $856 \mathrm{~B}$ is the occurrence of anhydrite, which Leybourne and Goodfellow identify as one of the key secondary minerals characterizing their Unit III. Table 2 lists the occurrences of anhydrite, gypsum, barite, and tabular crystal molds documented in Holes $856 \mathrm{~A}$ and 856B. Both gypsum and molds are believed to have formed from anhydrite, by hydration and dissolution, respectively. It is apparent that anhydrite and its alteration products are more widely distributed throughout these two holes than was appreciated by the Shipboard Scientific Party (1992). In particular, Kurnosov et al. (this volume) detected anhydrite both visually and by X-ray diffraction virtually throughout both holes, including in the relatively unaltered part of Unit IIA (Unit IV of Leybourne and Goodfellow, this volume), at depths as shallow as $6 \mathrm{mbsf}$ in both holes. Anhydrite still probably formed in greater abundance in Unit IIC (Unit III of Leybourne and Goodfellow), however, as the lathshaped crystal molds are much more abundant there than elsewhere.

Within the massive sulfide body itself, which was drilled to a depth of 94 mbsf, hemipelagic and turbiditic sediment are nearly absent. Only seven pieces of such sediment were recovered, all from a single interval between 25 and $30 \mathrm{mbsf}$ in a single hole, $856 \mathrm{H}$. No such samples were recovered from Hole $856 \mathrm{G}$, only $35 \mathrm{~m}$ away, in spite of the fact that it cored the same depth interval. That these strata are apparently discontinuous led the Shipboard Scientific Party (1992) to speculate that the few samples recovered from Hole $856 \mathrm{H}$ came from small ponds of sediment that may have accumulated in irregularities on the surface of the sulfide deposit while it was forming. 
Figure 2. SeaMARC I sidescan acoustic image showing Bent Hill (Holes $856 \mathrm{~A}$ and $856 \mathrm{~B}$ ), the massive sulfide deposit (Holes 856C-856H), and the mound of sulfide rubble to the south with active venting at $265^{\circ} \mathrm{C}$. Heat flow is shown in $\mathrm{mW} / \mathrm{m}^{2}$.

\section{SEQUENCE AND TIMING OF KEY EVENTS}

Based on the above information, and data on pore-water composition to be presented below, we suggest the following sequence of events for the sediment in Holes 856A and 856B:

1. The massive sulfide deposit began to form during the Pleistocene by precipitation from high-temperature $\left(>350^{\circ} \mathrm{C}\right)$ fluids within a hydrothermal upflow zone. Sediment in Hole $856 \mathrm{~A}$ and particularly in Hole 856B, which was closer to the upflow zone, became hydrothermally altered. The deposit formed rapidly and/or remained highstanding throughout its formation, such that it contains few, if any, hemipelagic or turbiditic interbeds.

2. After at least part of the deposit had formed and been surficially weathered and oxidized, sulfide clasts slumped downhill from the deposit repeatedly and were redeposited as graded beds in the vicinity of Hole $856 \mathrm{~B}$, forming the middle interval of Unit IIB. These slump deposits did not reach Hole 856A only $190 \mathrm{~m}$ to the north.

3. Twelve to $38 \mathrm{~m}$ of Pleistocene interbedded hemipelagic and turbiditic sediment accumulated on top of these sulfide slump deposits, followed by less than $1 \mathrm{~m}$ of Holocene hemipelagic sediment.

4. Sills were intruded locally, causing the uplift of Bent Hill and additional heating and alteration of the sediment. This alteration

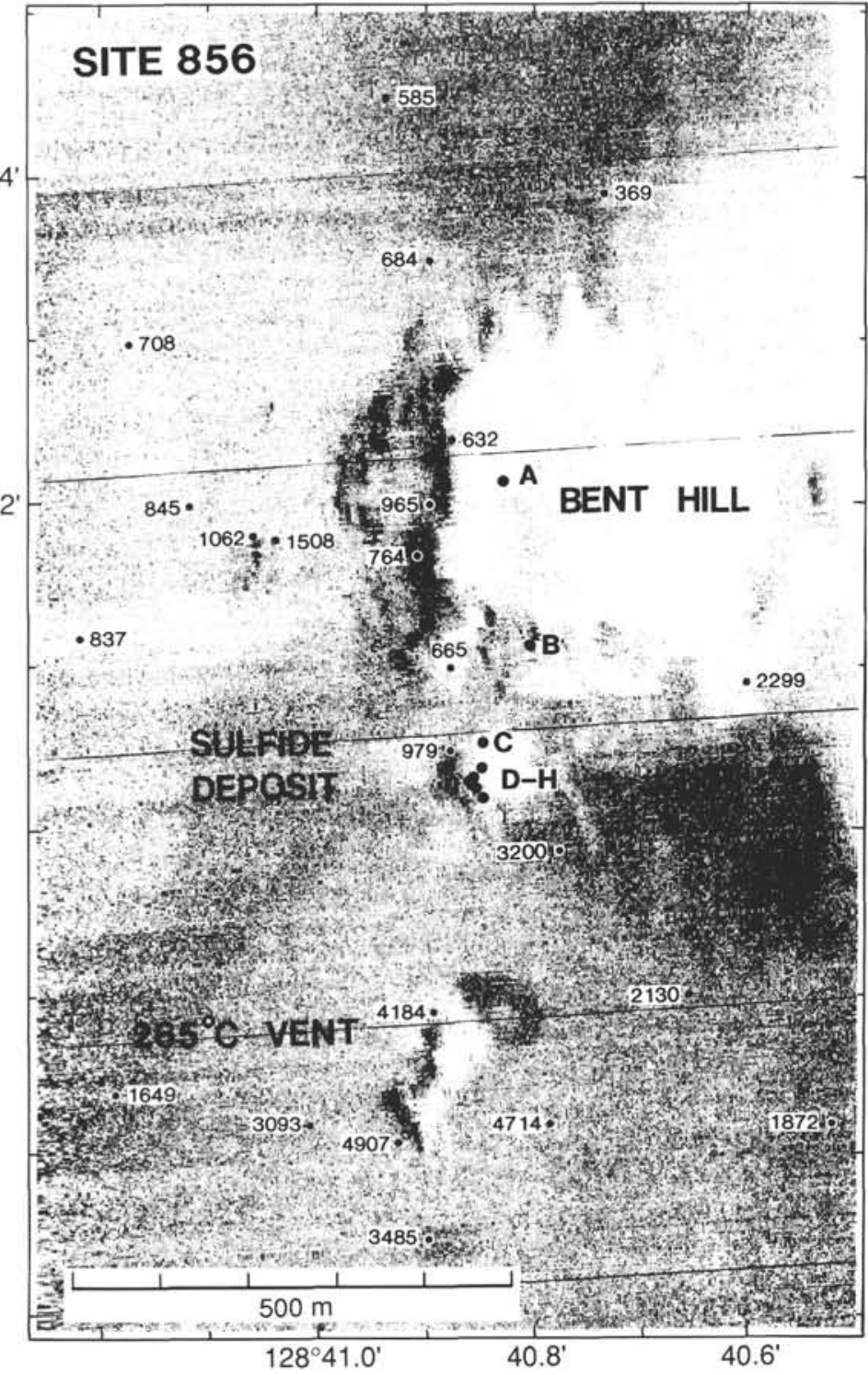

included precipitation of anhydrite from seawater that was convecting thermally through the sediment. These intrusive events may also have caused up to $21 \mathrm{~m}$ of Pleistocene and Holocene sediment to slump from the south flank of Bent Hill, forming the step on which Hole 856B is located (Figs. 2 and 3).

5. The sills cooled, but their cooling was accompanied by continued local circulation of seawater through the sediment. This circulating seawater became progressively less altered with time. Anhydrite began to redissolve.

6. As the circulation slowed and then stopped, microbially mediated reactions in the sediment produced profiles of dissolved sulfate, ammonium, and calcium in the surficial sediments, to $17 \mathrm{mbsf}$, that are similar in Holes 856A and 856B.

The important implication of this scenario is that the massive sulfide deposit formed largely in the Pleistocene, whereas the nearby hill was uplifted in the Holocene.

\section{SUPPORTING EVIDENCE}

We present here additional evidence supporting this scenario, in particular that the sills were intruded later than the bulk of alteration associated with formation of the massive sulfide deposit. A key link in 


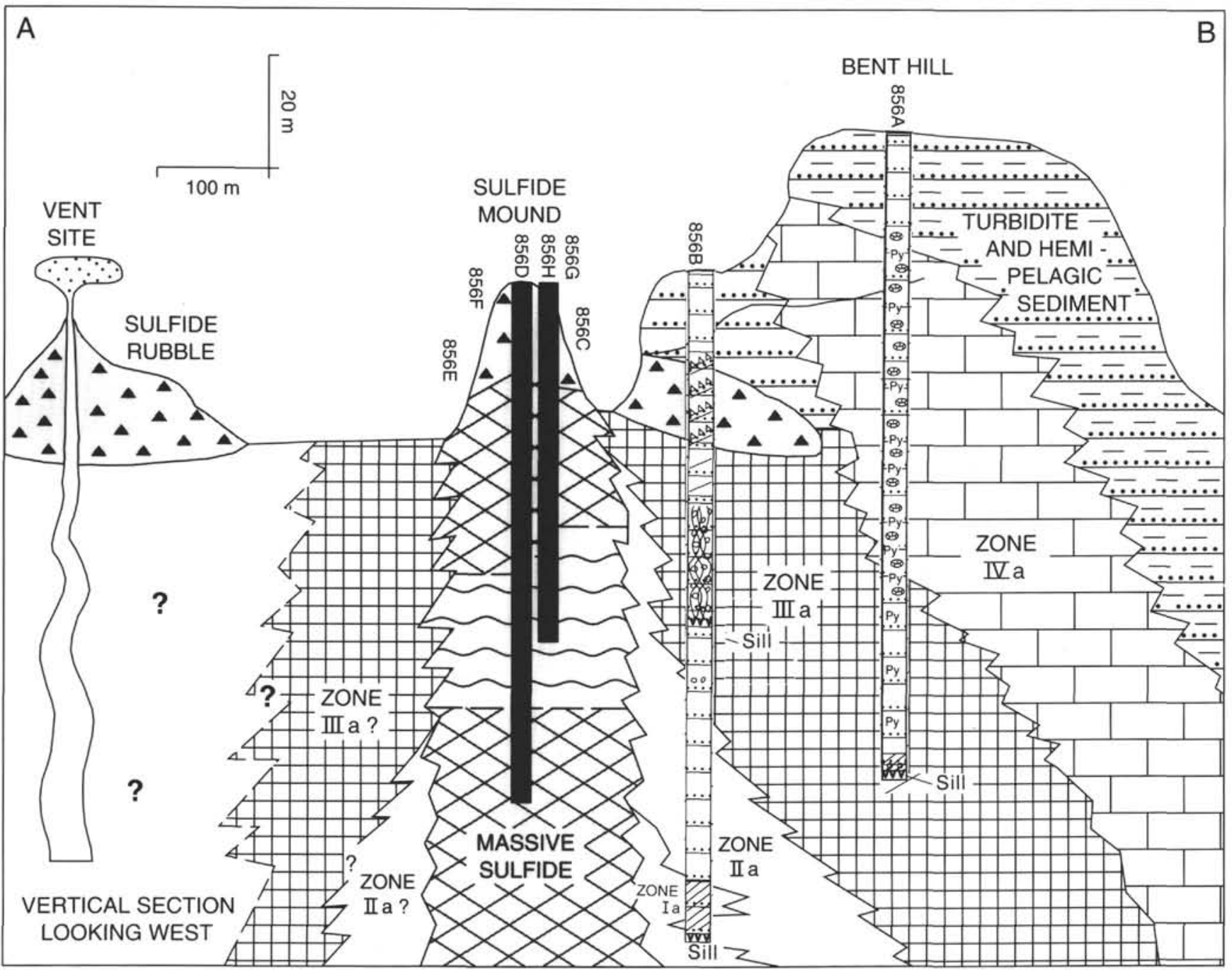

Figure 3. South-north cross section of the active vent site, the massive sulfide deposit, and Bent Hill, showing the alteration zones of Leybourne and Goodfellow (this volume) relative to the drill holes.

our reasoning that we cannot demonstrate is that intrusion of the sills caused uplift of Bent Hill and slumping of sediment from its south flank. The presence of Holocene sediment atop Bent Hill and its absence over the sulfide deposit, however, is certainly consistent with Holocene uplift of the hill, as is the presence of Pleistocene sediment overlying clastic massive sulfide in Hole $856 \mathrm{~B}$, compared with its near absence within or on the deposit. It is difficult to see how Pleistocene and Holocene sediment could have accumulated atop a 60-m-high hill but not on an adjacent sulfide body that stands only $30 \mathrm{~m}$ high. It seems much more likely that these sediments had largely accumulated prior to uplift of the hill. As for the slumping from the south flank, the presence of Holocene sediment in Hole 856 A and its absence in Hole $856 \mathrm{~B}$ clearly indicate that this took place in the Holocene.

\section{Stratigraphy}

Unit IIB is important because it indicates that at the time of redeposition of the clastic sulfide, the site of Hole 856B was deeper than a local source of sulfide debris. The only likely source is the massive sulfide deposit $100 \mathrm{~m}$ to the south. At present the top of this deposit lies $3 \mathrm{~m}$ deeper than the seafloor at Hole 856B, even though as much as $21 \mathrm{~m}$ of sediment has apparently slumped from Bent Hill at the location of Hole $856 \mathrm{~B}$. This indicates that either the deposit has sunk or the hill has risen since Unit IIB was deposited. In addition to what may have slumped, $18 \mathrm{~m}$ of interbedded hemipelagic and turbiditic sediment of Pleistocene age still overlies the middle interval of Unit IIB in Hole 856B, indicating that massive sulfide began to form in the Pleistocene. The most likely explanation for these relationships is that Bent Hill was uplifted after at least some of the massive sulfide had precipitated.

Sedimentation rates at Site 856 have been estimated by a variety of methods. Goodfellow and Blaise (1988) estimated a Holocene sedimentation rate of $6 \mathrm{~cm} / \mathrm{k} . \mathrm{y}$. for a piston core from Bent Hill, based on ${ }^{14} \mathrm{C}$ dating of Globigerina bulloides. Brunner (this volume) calculated a rate of $<8 \mathrm{~cm} / \mathrm{k}$.y: for the less than $1 \mathrm{~m}$ of Holocene sediment in Hole $856 \mathrm{~A}$, as determined from zonation based on the coiling direction of Neogioboquadrina pachyderma. For the upper Pleistocene in this hole, to $125,000 \mathrm{yr}$ and $20.1 \mathrm{mbsf}$, she estimated a rate of $17 \mathrm{~cm} / \mathrm{k} . \mathrm{y}$. Mao and Wise (this volume) found a rate of $24 \mathrm{~cm} / \mathrm{k} . \mathrm{y}$. for the upper Pleistocene to $73,000 \mathrm{yr}$ and $14.4 \mathrm{mbsf}$ in Hole $856 \mathrm{~A}$, based on the depth to the Emiliania huxleyi Acme Zone. These rates are generally lower than those determined for the upper Pleistocene at Sites 855 (23 to $24 \mathrm{~cm} / \mathrm{k}$.y.: Mao and Wise, this volume; $28 \mathrm{~cm} / \mathrm{k}$.y. based on radiolarians: S.V. Tochlina, unpubl. data), $857(33 \mathrm{~cm} / \mathrm{k} . \mathrm{y} .:$ Brunner, this volume), and 858 (40 cm/k.y.: Goodfellow and Peter, this volume). Sedimentation rates must have been considerably higher than any of these values earlier in the Pleistocene in order to accumulate the approximately $400 \mathrm{~m}$ of sediment that overlies acoustic basement at 
Table 2. Sulfate minerals and tabular crystal molds in Holes 856A and 856B.

\begin{tabular}{|c|c|c|c|c|c|c|}
\hline $\begin{array}{l}\text { Core, section, } \\
\text { interval }(\mathrm{cm})\end{array}$ & $\begin{array}{l}\text { Depth } \\
\text { (mbsf) }\end{array}$ & $\begin{array}{c}\text { Lithostratigraphic } \\
\text { unit }^{\mathrm{a}}\end{array}$ & $\begin{array}{c}\text { Alternate } \\
\text { unit }^{\mathrm{b}}\end{array}$ & Method $^{\mathrm{C}}$ & Mineral & Reference $^{d}$ \\
\hline \multicolumn{7}{|l|}{ 139-856A- } \\
\hline $2 \mathrm{H}-3,67-69$ & 6.37 & IIA & Unaltered & XRD & Anhydrite & 1 \\
\hline $5 \mathrm{H}-7,28-30$ & 39.34 & IIA & IV & XRD & Anhydrite & i \\
\hline $7 \mathrm{H}-2$ & 51.7 & IIA & IV & Visual & Anhydrite & 2 \\
\hline $7 \mathrm{H}-4,133-137$ & 56.03 & IIA & IV & XRD & Anhydrite, gypsum & 1 \\
\hline $8 \mathrm{H}-1,115-117$ & 60.85 & IIA & IV & XRD & Anhydrite & 2 \\
\hline $8 \mathrm{H}-3,102-105$ & 63.72 & IIA & IV & XRD & Anhydrite & 2 \\
\hline $9 \mathrm{H}-3, .56-59$ & 72.76 & IIA & IV & Visual $^{e}$ & Barite & $i$ \\
\hline $10 X-1,55-57$ & 79.25 & IIA & IV & Visual $^{e}$ & Anhydrite & i \\
\hline $11 X-1$ & 86.2 & IIC & III & Visual & Anhydrite & 2 \\
\hline $13 \mathrm{X}-1,108-111$ & 106.38 & IIC & III & XRD & Anhydrite & $i$ \\
\hline $13 \mathrm{X}-3,93-97$ & 109.23 & IIC & III & Visual $^{e}$ & Barite & $\mathrm{i}$ \\
\hline $11 \mathrm{X}$ through $13 \mathrm{X}, 87-113$ & & & III & Visual & Molds & 2 \\
\hline \multicolumn{7}{|l|}{ 139-856B- } \\
\hline $\mathrm{IH}-1,33-37$ & 0.33 & IIA & Unaltered & Visual $^{\mathrm{e}}$ & Barite & 1 \\
\hline $2 \mathrm{H}-3,106-110$ & 5.88 & IIA & Unaltered & Visual $^{\mathrm{e}}$ & Anhydrite & $i$ \\
\hline $3 \mathrm{H}-1,108-110$ & 12.38 & IIB & Slump & Visual & Anhydrite, gypsum & i \\
\hline $3 \mathrm{H}-2,60-62$ & 13.38 & IIB & Slump & XRD & Anhydrite, gypsum & 1 \\
\hline $3 \mathrm{H}-4,64-66$ & 16.42 & IIB & Slump & XRD & Anhydrite & i \\
\hline $3 \mathrm{H}-6,34-36$ & 19.14 & IIB & Slump & Visual & Anhydrite & 3 \\
\hline $4 \mathrm{H}-4,67-68$ & 25.97 & IIB & Slump & Visual $^{\mathrm{e}}$ & Anhydrite & 1 \\
\hline $5 \mathrm{H}-4,110-115$ & 35.90 & IIA & Unaltered & XRD & Anhydrite, gypsum & 4 \\
\hline $6 \mathrm{H}-4,95-97$ & 45.25 & IIC & III & XRD & Anhydrite & 1 \\
\hline $7 \mathrm{H}-3,89-92$ & 53.19 & IIC & III & Visual & Anhydrite, gypsum & 5 \\
\hline $7 \mathrm{H}-4,46-49$ & 54.26 & IIC & III & Visual $^{e}$ & Barite & 1 \\
\hline $9 X-1,55-59$ & 62.87 & IIC & III & Visual $^{e}$ & Anhydrite & 1 \\
\hline $6 \mathrm{H}$ through $9 \mathrm{X}, 40-66$ & & IIC & III & Visual & Molds & 2 \\
\hline $13 X-1,69-73$ & 91.81 & IID & II & Visual $^{e}$ & Anhydrite & 1 \\
\hline $15 \times-5,34-36$ & 116.74 & IID & I & Visual & Anhydrite & 5 \\
\hline $15 X-5,119-121$ & 117.59 & IID & I & Visual & Anhydrite & 5 \\
\hline $15 \mathrm{X}-\mathrm{CC}, 12-14$ & 118.14 & IID & i & Visual & Barite & 5 \\
\hline $15 \mathrm{X}-\mathrm{CC}, 20-22$ & 118.22 & IID & I & Visual & Barite & 2,3 \\
\hline $16 \mathrm{X}-1,17-19$ & 120.27 & IID & i & Visual & Barite & 5 \\
\hline \multicolumn{7}{|c|}{$\begin{array}{l}\text { Shipboard Scientific Party (1992). } \\
\text { Leyboume and Goodfellow (this volume). } \\
\text { XRD =X-ray diffraction. } \\
\text { d } 1=\text { Kurnosov et al. (this volume); } 2 \text { = Shipboard Scientific Party (1992); } 3 \text { = Leybourne and Goodfellow (this volume); } \\
\quad 4=\text { Buatier et al. (this volume); } 5 \text { = Zierenberg (this volume). } \\
\text { e Visual by oil-immersion microscopy on heavy-mineral fraction, separated from coarse fraction ( } 0.1-0.05 \text { mm) using heavy } \\
\text { liquids. In other samples labeled as "visual," sulfate minerals were identified by inspection of smear slides (references } \\
\text { 1,2), thin sections (references } 1.3 \text { ), unprocessed sediment and veins (reference } 5 \text { ), or by scanning electron microscopy } \\
\text { (reference } 3 \text { ). }\end{array}$} \\
\hline
\end{tabular}

Site 856 . If basement is as old as $320,000 \mathrm{yr}$, a mean rate of $>125$ $\mathrm{cm} / \mathrm{k} . \mathrm{y}$. is required.

At sedimentation rates of 20 to $125 \mathrm{~cm} / \mathrm{k}$.y., the $18 \mathrm{~m}$ of hemipelagic and turbiditic sediment overlying the clastic-sulfide-bearing interval in Unit IIB of Hole 856B would have required 14 to 90 k.y. to accumulate; an additional $21 \mathrm{~m}$ of sediment that probably slumped off, including $1 \mathrm{~m}$ of Holocene sediment, would have required another $125,000 \mathrm{yr}$, based on the age datum of Brunner (this volume) cited above. Thus, the clastic sulfide interbeds in Unit IIB were probably redeposited between about 140,000 and $220,000 \mathrm{yr}$ ago, and the massive sulfides that comprise them formed at least that long ago. The presence of similar clastic sulfide interbeds in Holocene sediments (Goodfellow and Franklin, in press) indicates that the deposit slumped much later as well; the relative freshness of the sulfide minerals in these Holocene interbeds suggests that massive sulfide may have precipitated repeatedly at Site 856 , over a long period of time.

\section{Temperature Profiles: Present and Past}

The temperature profiles measured in the sedimentary section in Holes 856A and 856B (Shipboard Scientific Party, 1992) are compared with paleotemperatures estimated from geochemical data in Figure 4. Paleotemperatures have been estimated from the oxygen isotopic composition of calcite nodules and cements (Baker et al., this volume; Früh-Green et al., this volume); vitrinite reflectance (Whelan et al., this volume), thermal alteration index, and spore fluorescence color (Mao et al., this volume); maturity of hydrocarbons, including the isoprenoid- to-normal hydrocarbon ratio (Shipboard Scientific Party, 1992; Simoneit, this volume; $<0.5$ implies $>50^{\circ} \mathrm{C}$ ), the absence of alkenones (Simoneit et al., this volume; absence implies $\geq 200^{\circ} \mathrm{C}$ for a brief period or lower temperatures of $20^{\circ}$ to $80^{\circ} \mathrm{C}$ for hundreds of years) and alkanes (Boni et al., this volume), and dominance of polyaromatic hydrocarbons (Boni et al., this volume; Simoneit, this volume; dominance implies $>200^{\circ}-250^{\circ} \mathrm{C}$ ); and fluid inclusion microthermometry on quartz (Peter et al., this volume).

The data clearly show that both Holes $856 \mathrm{~A}$ and $856 \mathrm{~B}$ were much hotter in the past than they are at present. Whereas the present-day temperatures at the base of the drilled sediment section are $58^{\circ} \mathrm{C}$ in Hole $856 \mathrm{~A}$ and about $155^{\circ} \mathrm{C}$ in Hole $856 \mathrm{~B}$, the estimated paleotemperatures at those depths exceeded $280^{\circ} \mathrm{C}$ and $338^{\circ} \mathrm{C}$, respectively. Of particular interest is the fact that both holes show high paleotemperatures to shallow depths, consistent with the occurrence of anhydrite at these depths noted above. Hole $856 \mathrm{~A}$ exceeded $50^{\circ} \mathrm{C}$ at only 14 mbsf and reached nearly $100^{\circ} \mathrm{C}$ at 20 mbsf. These depths correspond to the two biostratigraphic datums cited above, which were dated at $73,000 \mathrm{yr}$ (Mao and Wise, this volume) and 125,000 yr (Brunner, this volume), respectively. The sediment column thus has been heated nearly throughout its length sometime in the past 70,000 yr and, based on the occurrence of anhydrite at only 6 mbsf (Table 2), probably within the past $40,000 \mathrm{yr}$, much more recently than the date estimated above by which massive sulfide had begun to form. At Hole 856B, paleotemperatures exceeded $200^{\circ} \mathrm{C}$ at depths as shallow as $1.8 \mathrm{mbsf}$, consistent with evidence that the upper sediment column is missing at the location of this hole. Only the sample from $0.48 \mathrm{mbsf}$ is estimated by Mao et al. (this volume) not to have exceeded $65^{\circ} \mathrm{C}$, based on its vitrinite reflectance and thermal alteration index. Several temperature estimates in excess of $50^{\circ}$ to $200^{\circ} \mathrm{C}$ come from sediment that overlies the beds of clastic massive sulfide of Unit IIB, both from 
the upper hemipelagic-turbiditic interval of Unit IIB and from Unit IIA, reinforcing the inference of intense heating that greatly postdates the beginning of massive sulfide deposition.

The proximity of Holes $856 \mathrm{~A}$ and $856 \mathrm{~B}$ to the massive sulfide deposit makes it all but certain that a major amount of alteration observed in these holes was accomplished by the upwelling hydrothermal solutions that formed the deposit. This conclusion is confirmed by the high sulfur content of the sediments at Site 856, especially in Hole $856 \mathrm{~B}$, which exceeds that at Sites 855 and 857 and is comparable to that at Site 858 (Shipboard Scientific Party, 1992). The alteration documented in the uppermost sediment, however, probably postdates formation of the bulk of the deposit. It could have been caused instead by intrusion of shallow sills, three of which were penetrated in the holes, or by the kind of lower temperature $\left(265^{\circ} \mathrm{C}\right)$ hydrothermal venting that is still active $500 \mathrm{~m}$ south of Hole $856 \mathrm{~B}$. As documented at Site 858 , this type of hydrothermal activity, at $\angle 300^{\circ} \mathrm{C}$, is too low-temperature to form a substantial massive sulfide deposit. The relationship of this activity to intrusion of the shallow sills is poorly known, but the presence of hydrothermal solutions at $<300^{\circ} \mathrm{C}$ nearly $1000 \mathrm{mbsf}$ at Site 857 and venting at the seafloor at Site 858 indicates that intrusion of shallow sills is not required to drive such circulation. In any case, it is highly likely that hydrothermal solutions have upwelled repeatedly, if not continuously, at or near Site 856.

The lateral temperature gradient that exists today between Holes $856 \mathrm{~A}$ and $856 \mathrm{~B}$ was apparently even more extreme in the past (Fig. 4). Paleotemperatures in Hole $856 \mathrm{~A}$ between 20 and $40 \mathrm{mbsf}$ range from $50^{\circ}$ to $120^{\circ} \mathrm{C}$. If about $20 \mathrm{~m}$ of sediment has been lost at Hole $856 \mathrm{~B}$, the comparable depth range there would be 0 to $20 \mathrm{mbsf}$, for which the paleotemperature range is $120^{\circ}$ to $200^{\circ} \mathrm{C}$. The evidence implies changes in time as well as in space. Paleotemperatures estimated from the oxygen isotopic composition of calcite nodules and cements in Hole 856A are generally lower than those estimated from indices of hydrocarbon maturity. The isotopic estimates are minima, however, because the nodules were assumed to have grown from seawater rather than from an ${ }^{18} \mathrm{O}$-enriched solution. Based on analyses of hydrocarbons in the nodules, Boni et al. (this volume) concluded that the hydrocarbons matured before the nodules formed, consistent with formation of the nodules at a lower temperature, although Früh-Green et al. (this volume) found that the formation temperature calculated for the nodules increases from core to rim, indicating a prograde sequence. The nodules typically exhibit recrystallization, suggesting a complex history. That the nodules occur as shallow as $14 \mathrm{mbsf}$ in Hole $856 \mathrm{~A}$, near the $73,000 \mathrm{yr}$ datum of Mao and Wise (this volume), indicates that at least some of them formed during a relatively late episode of heating (Baker et al., this volume), long after the massive sulfide deposit began to form.

Baker et al. (this volume), Früh-Green et al. (this volume), and Mao et al. (this volume) all detected a disturbance in an otherwise monotonic paleotemperature gradient in Hole $856 \mathrm{~A}$, between about 52 and $60 \mathrm{mbsf}$, where anomalously high temperatures were recorded (Fig. 4). They suggested that this disturbance could have resulted from intrusion of the sill at $62 \mathrm{mbsf}$ in Hole 856B. Of course, this sill did not extend laterally as far as Hole 856A, $190 \mathrm{~m}$ away, but its correlative depth in Hole $856 \mathrm{~A}$ would be $87 \mathrm{mbsf}$ if it were extended horizontally (Fig. 3), not 52 to $60 \mathrm{mbsf}$, casting doubt on this interpretation. Mao et al. (this volume) noted as well a sharp inflection in the vitrinite reflectance data from just above the sill at $62 \mathrm{mbsf}$ in Hole $856 \mathrm{~B}$, which they attributed to the thermal effects of intrusion of this sill. Unfortunately, the data do not constrain whether this higher vitrinite reflectance was produced before or after the background gradient in this property.

\section{Nature and Effect of the Sills in Holes 856A and 856B}

The hills in the eastern third of Middle Valley, such as Bent Hill, are cored by bright seismic reflectors interpreted to be sills or laccoliths. The hills were probably uplifted by these intrusions, some of

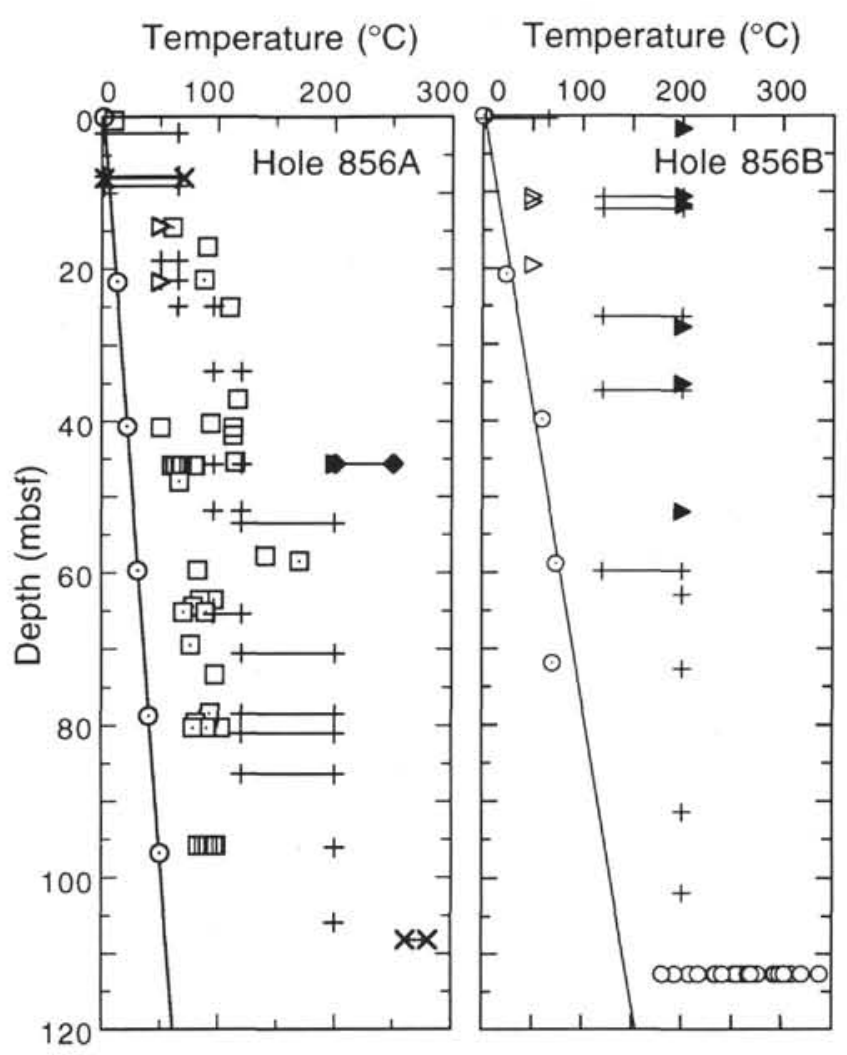

Figure 4. Present temperature gradients measured in Holes $856 \mathrm{~A}$ and $856 \mathrm{~B}$ (Shipboard Scientific Party, 1992; dotted circles and best-fit line), compared with paleotemperatures inferred from geochemical data by Früh-Green et al. (this volume; open squares), Baker et al. (this volume; dotted squares), Mao et al. (this volume; crosses), Whelan et al. (this volume; X's), Simoneit (this volume; open triangles), Simoneit et al. (this volume; solid triangles), Boni et al. (this volume; diamonds), and Peter et al. (this volume; open circles).

which were emplaced within $25 \mathrm{~m}$ of the present seafloor and are therefore less than a few tens of thousands of years old (Davis and Villinger, 1992). The three sills intersected by drilling into Bent Hill, while too shallow to produce the seismic reflector detected at about $150 \mathrm{mbsf}$, are probably typical of the intrusions that core these hills. The three sills are low-potassium, picritic tholeiites. They are the most primitive mafic rocks ever recovered from the Juan de Fuca Ridge, with an average of $9.4 \%$ olivine in the norm, and are distinct from any other mafic rocks drilled on Leg 139 . Their chemical variation cannot be explained by fractional crystallization, either in situ or in a shallow-level magma chamber, but reflects instead variable melting at a pressure of about 5 to $6 \mathrm{kbar}$. The magma that formed these basalts probably came directly from the mantle; as it did not produce a crustal magma chamber, it could not have provided enough heat to form the large massive sulfide deposit at Site 856 (Shipboard Scientific Party, 1992). These conclusions further support the separation in time between formation of most of the sulfide deposit and uplift of Bent Hill.

As noted above, the alteration caused by intrusion of the sills is minimal compared with that produced in the major hydrothermal upflow zone. This is the case for the physical as well as the chemical data. The discrete-sample data for porosity and $P$-wave velocity are sparse but show no effect of the sills. Porosity decreases regularly with depth from $80 \%$ to $50 \%$ within both Holes $856 \mathrm{~A}$ and $856 \mathrm{~B}$. The $P$-wave logger data for velocity are highly scattered and show at most an irregular increase in Hole $856 \mathrm{~B}$ from about $53 \mathrm{mbsf}$ to the top of the first sill at $62 \mathrm{mbsf}$. There is no evidence for a large reduction in porosity such as was found by Einsele et al. (1980) in sediment above 


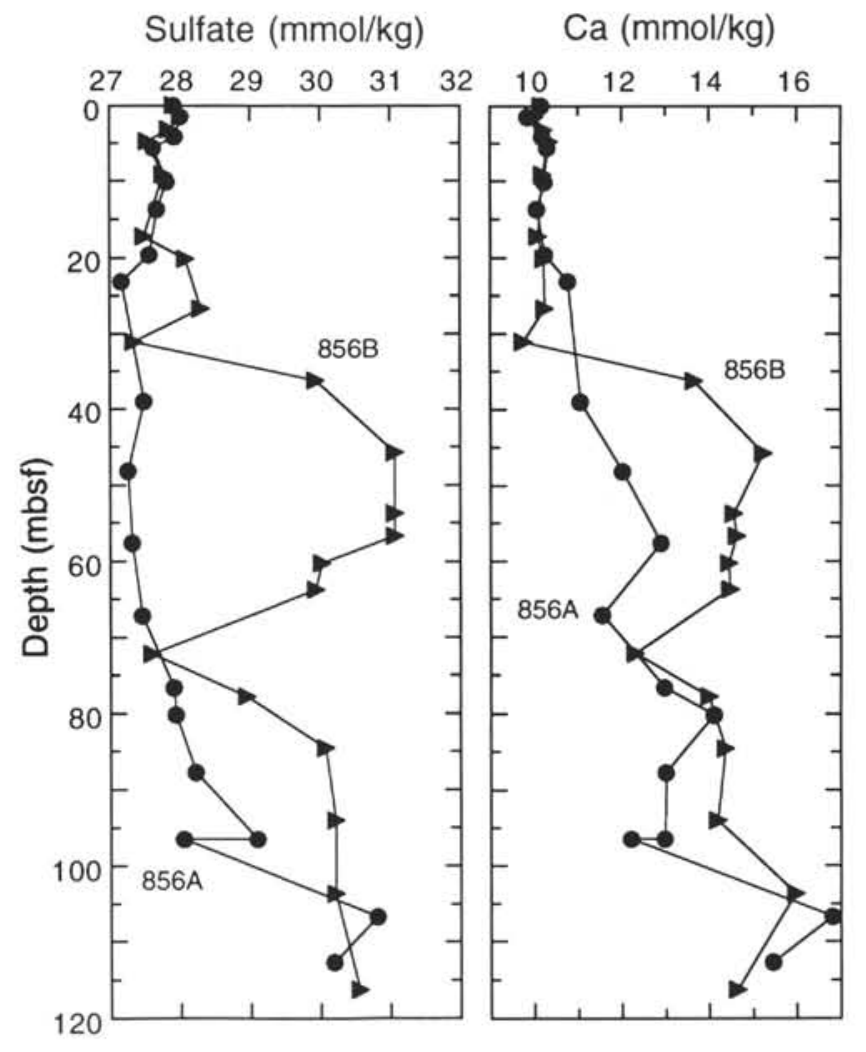

Figure 5. Composition of sediment pore waters from Holes $856 \mathrm{~A}$ and $856 \mathrm{~B}$.

and below sills drilled in the Guaymas Basin on Leg 64 of the Deep Sea Drilling Project.

Nonetheless, the abundance of anhydrite, as reflected especially in the presence of crystal molds, appears to be greatest above the sills in both Holes $856 \mathrm{~A}$ and $856 \mathrm{~B}$ (Table 2). The concentrations of dissolved sulfate and calcium in the sediment pore water are also highest near the sills (Fig. 5). The maxima in dissolved sulfate just above all three sills, and especially the minimum at 72 mbsf in Hole 856B, at a depth between the two sills in that hole, are best explained by ongoing dissolution of anhydrite that was originally most abundant near the sills. These relationships strongly suggest that much of the anhydrite precipitated from pore water when the sediment was heated by intrusion of the sills. As most high-temperature hydrothermal solutions contain elevated concentrations of calcium but little dissolved sulfate, precipitation of substantial quantities of anhydrite requires that relatively unaltered seawater be available, as would be the case if a sill were intruded into sediment containing pore water such as that at Site 855 , which retains most of its dissolved sulfate. The heat of the intrusion could initiate hydrothermal convection locally, drawing in additional unaltered seawater.

Anhydrite will precipitate not only on heating of seawater, however, but also on mixing of sulfate-rich seawater with a calcium-rich hydrothermal solution. An alternative explanation for the anhydrite at Site 856, therefore, is mixing at the edge of the hydrothermal upflow zone, where unaltered seawater would also tend to be drawn in as part of local, secondary convection cells. Goodfellow and Peter (this volume) favor this explanation, and use it to explain as well the large magnesium enrichment that begins at about 50 mbsf in Hole $856 \mathrm{~A}$ and $18 \mathrm{mbsf}$ in Hole $856 \mathrm{~B}$, and reaches a maximum in Units IIC and IID (their Units III and II). Magnesium, like sulfate, is abundant in seawater but nearly absent in hydrothermal solutions. Hydrothermally altered sediment in the upflow zone at Site 858 shows a similar magnesium enrichment, indicating that the enrichment at Site 856 could have occurred either during formation of the sulfide deposit or during later upwelling at $<300^{\circ} \mathrm{C}$, as is presently occurring just south of the deposit. We conclude that anhydrite probably precipitated both during hydrothermal upwelling and on intrusion of the sills.

Anhydrite or gypsum will precipitate at temperatures less than $100^{\circ} \mathrm{C}$ if the calcium concentration is more than twice that in seawater, and at $150^{\circ} \mathrm{C}$ or at higher temperatures with little or no calcium enhancement (Seyfried and Bischoff, 1979). The calcium concentration of the solutions presently venting in Middle Valley, which are essentially sulfate-free, is $40 \mathrm{mmol} / \mathrm{kg}$ south of Site 856 and 81 $\mathrm{mmol} / \mathrm{kg}$ at Site 858 (Butterfield et al., this volume). The higher-temperature solutions that deposited the massive sulfide deposit at Site 856 probably contained about $20 \mathrm{mmol} / \mathrm{kg}$ calcium. The fluid inclusion data of Peter et al. (this volume) indicate that anhydrite precipitated between $137^{\circ}$ and $311^{\circ} \mathrm{C}$ at Site 858 . Although no comparable data were collected for Site 856 , it is likely that the anhydrite there precipitated within a similar temperature range.

\section{Sediment Pore Waters}

Unlike sediments, which record the entire complex history of their hydrothermal alteration, sediment pore waters tend to retain a record only of the more recent and ongoing processes. This is the case at Site 856 . Sediment pore waters from Holes $856 \mathrm{~A}$ and $856 \mathrm{~B}$ are compared with those from the upper $120 \mathrm{mbsf}$ at the other three sites drilled in Middle Valley in Figures 6 through 9. Data are from Davis, Mottl, Fisher, et al. (1992) and Wheat and Mottl (this volume). The general conclusion is that the pore waters are more similar to bottom seawater at Site 856 than at any of the other sites over this depth interval. This indicates that they have reacted less with sediment and basement, even though the present temperatures at Site 856 are hotter than at some of the other sites. For comparison, the approximate temperatures at 70 mbsf are given in Table 3 for the sites and holes shown in Figures 6 through 9.

Site 855 was drilled $3.2 \mathrm{~km}$ east-northeast of Site 856 , at the eastern boundary fault of Middle Valley, and proved to be a locus of downwelling of seawater either directly into basement through outcrops at the base of the fault scarp, or along the fault itself. The pore waters have reacted extensively with the sediment, chiefly by microbial reduction of sulfate, but their composition returns again toward that of bottom seawater as the basement interface is approached. Site 857 is located $2.3 \mathrm{~km}$ west-northwest of Site 856 . Four holes were drilled there within $200 \mathrm{~m}$ of one another, on a thermal high thought to overlie a hydrothermal reservoir. The pore-water profiles indicate lateral flow at various depths but no vertical flow. Reaction within the upper 100 mbsf is dominated by bacterial degradation of organic matter, as at Site 855 , but seawater-rock reactions take over at greater depth as temperature increases, to nearly $300^{\circ} \mathrm{C}$ at the greatest depth drilled, 936 mbsf. Site 858 is a hydrothermal discharge site $3.2 \mathrm{~km}$ northwest of Site 856. Seven holes were drilled there within $230 \mathrm{~m}$ of one another, from just outside the upflow zone to an area where hot water is venting at temperatures up to $276^{\circ} \mathrm{C}$. Only the two holes from just outside and just inside the upflow zone are shown in Figures 6 through 9 , however, as the complexities nearer the vents are in no way comparable to the profiles at Site 856.

\section{Chlorinity}

Chlorinity increases above the value in bottom seawater at all sites except Site 856 (Fig. 6). Site 855 shows the typical $2 \%$ maximum at about $30 \mathrm{mbsf}$ that records the glacial-to-interglacial change in the salinity of ocean bottom water. At the peak of the last glacial period about 18,000 yr ago (Imbrie et al., 1984), bottom water was about $3.7 \%$ more saline than it is today (McDuff, 1985). Since then the chlorinity maximum recorded in the pore water has decreased to about $2 \%$ by upward diffusion of chloride. The presence of this peak precludes vertical flow through the sediment at any time in the past $18,000 \mathrm{yr}$ at velocities greater than about $1 \mathrm{~mm} / \mathrm{yr}$ (McDuff, 1985). With increasing depth below this maximum, as basement is approached, chlorinity at 
Table 3. Temperatures and temperature gradients at Sites 855 through 858.

\begin{tabular}{|c|c|c|c|}
\hline Hole & $\begin{array}{l}\text { Temperature } \\
\qquad\left({ }^{\circ} \mathrm{C}\right)^{\mathrm{a}}\end{array}$ & $\begin{array}{l}\text { Gradient } \\
\left({ }^{\circ} \mathrm{C} / \mathrm{m}\right)\end{array}$ & $\begin{array}{l}\text { Depth }^{\mathrm{b}} \\
\text { (mbsf) }\end{array}$ \\
\hline $855 \mathrm{~A}-\mathrm{D}$ & 25 & 0.328 & $0-76.3$ \\
\hline $856 \mathrm{~A}$ & 37 & 0.50 & $0-96.8$ \\
\hline $857 \mathrm{~A}-\mathrm{B}$ & 45 & 0.612 & $0-86.9$ \\
\hline $857 \mathrm{C}$ & 51 & 0.71 & $0-77.2$ \\
\hline $856 \mathrm{~B}$ & 91 & 1.27 & $0-58.8$ \\
\hline $858 \mathrm{~A}$ & $110 \pm 10$ & Nonlinear & $0-62.5$ \\
\hline $858 \mathrm{C}$ & $200 \pm 10$ & Nonlinear & $0-42.6$ \\
\hline
\end{tabular}

Site 855 returns to the value in present-day bottom seawater. The Shipboard Scientific Party (1992) inferred from this that bottom seawater is entering basement through the eastern boundary fault of Middle Valley and flowing laterally through the basalts. The chlorinity maximum in Hole $858 \mathrm{C}$ could likewise reflect glacial bottom water, but here it probably results instead from lateral flow of the hydrothermal solution that upwells less than $100 \mathrm{~m}$ to the east, which has a chlorinity of $578 \mathrm{mmol} / \mathrm{kg}$ (Butterfield et al., this volume). Lateral flow through the sediments has been documented at both Sites 857 and 858 (Shipboard Scientific Party, 1992). Chlorinity at Sites 857 and 858 increases steadily with depth over the upper 120 mbsf because the altered seawater circulating at depth through the sediment and/or basement is more saline than bottom seawater.

Chlorinity at Site 856 stands in marked contrast to all the other sites in remaining constant at the value of present-day bottom seawater over the upper $60 \mathrm{mbsf}$. We suspect that the slight decrease between 60 and $120 \mathrm{mbsf}$, which is especially apparent in Hole 856B, results from contamination of the deeper cores with seawater as they were raised through the water column, as these cores are moderately indurated and fractured. Alternatively, altered seawater at depth may have a lower chlorinity that is affecting the deeper part of Hole $856 \mathrm{~B}$ by diffusion; the chlorinity of the $265^{\circ} \mathrm{C}$ vent $460 \mathrm{~m}$ south of Hole $856 \mathrm{~B}$ is only 412 $\mathrm{mmol} / \mathrm{kg}$ (Butterfield et al. this volume). The fact that chlorinity is essentially constant with depth strongly suggests that the sediment column at Site 856 has been flushed with bottom seawater sometime since the height of the last glaciation $18,000 \mathrm{yr}$ ago. The chlorinity of bottom water was about $560 \mathrm{mmol} / \mathrm{kg}$ then and has since decreased to 540 $\mathrm{mmol} / \mathrm{kg}$. That the constant value in the pore waters is nearly identical with the chlorinity of present-day bottom seawater suggests that the flushing occurred much more recently, within the last few thousand years. It may still be going on, although the near-linear thermal gradient in Hole 856A (Shipboard Scientific Party, 1992) and the general shape of the sediment pore-water profiles preclude vertical flow at velocities greater than $1 \mathrm{~cm} / \mathrm{yr}$. A likely cause of this flushing is intrusion of the shallow sills penetrated in Holes 856A and 856B.

Recent flushing of the sediment column with near-present-day bottom seawater is consistent with the relative lack of reaction between pore water and sediment indicated by the profiles of other dissolved species. Compared with Sites 855,857 , and 858 , the pore waters from Site 856 are most similar to seawater for chlorinity (Fig. 6), sulfate, alkalinity, ammonium, phosphate, manganese (Fig. 7), magnesium (Fig. 8), lithium, silica (Fig. 9), and dissolved organic carbon (Ran and Simoneit, this volume). This is in spite of the fact that temperatures are much hotter in Hole 856B than at comparable depths at Sites 855 and 857 (Table 3). Among the four sites, pore waters at Site 856 do not most closely resemble seawater for sodium, calcium, strontium, barium (Fig. 8), potassium, rubidium, and boron (Fig. 9).

\section{Sulfate, Alkalinity, Ammonium, Phosphate, Manganese, and Dissolved Organic Carbon}

Sulfate decreases substantially below the concentration in bottom seawater and alkalinity, ammonium, phosphate, and manganese in-
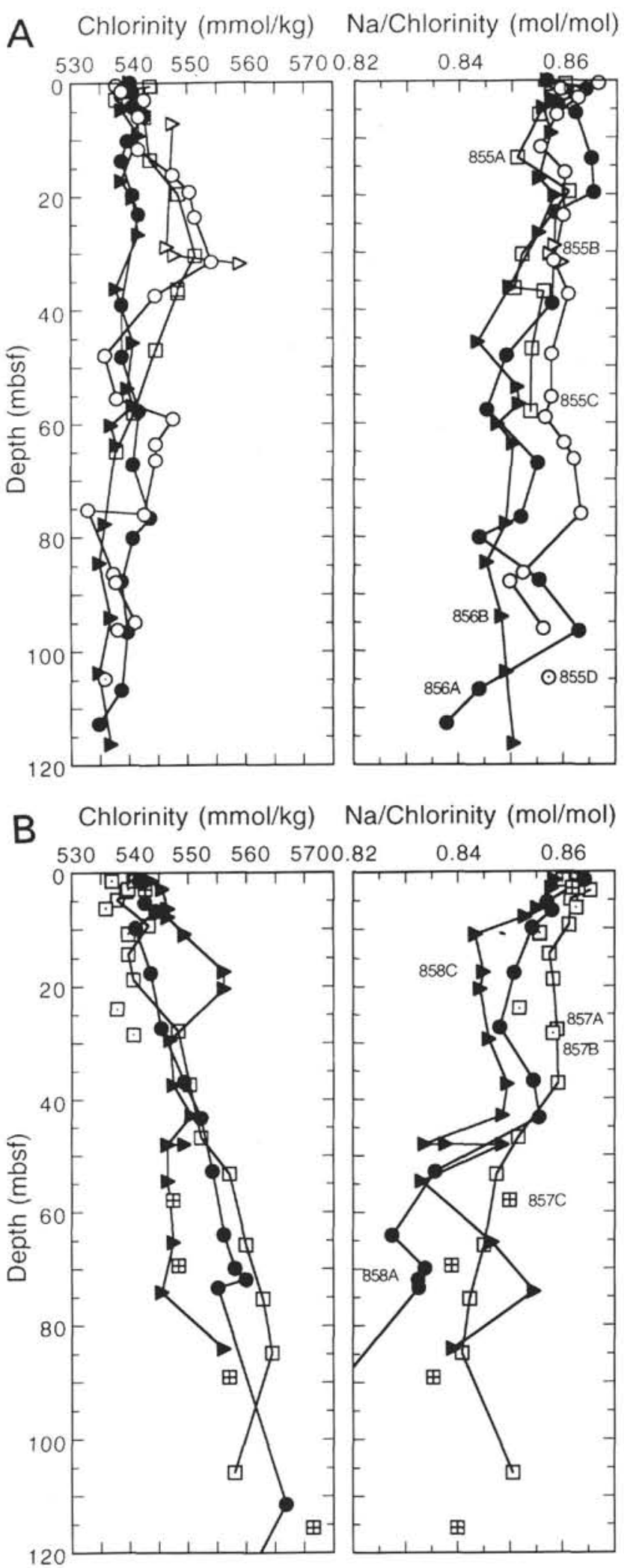

Figure 6. Composition of sediment pore waters from Sites 855 and 856 (A) and Sites 857 and $858(B)$, upper 120 mbsf only. 

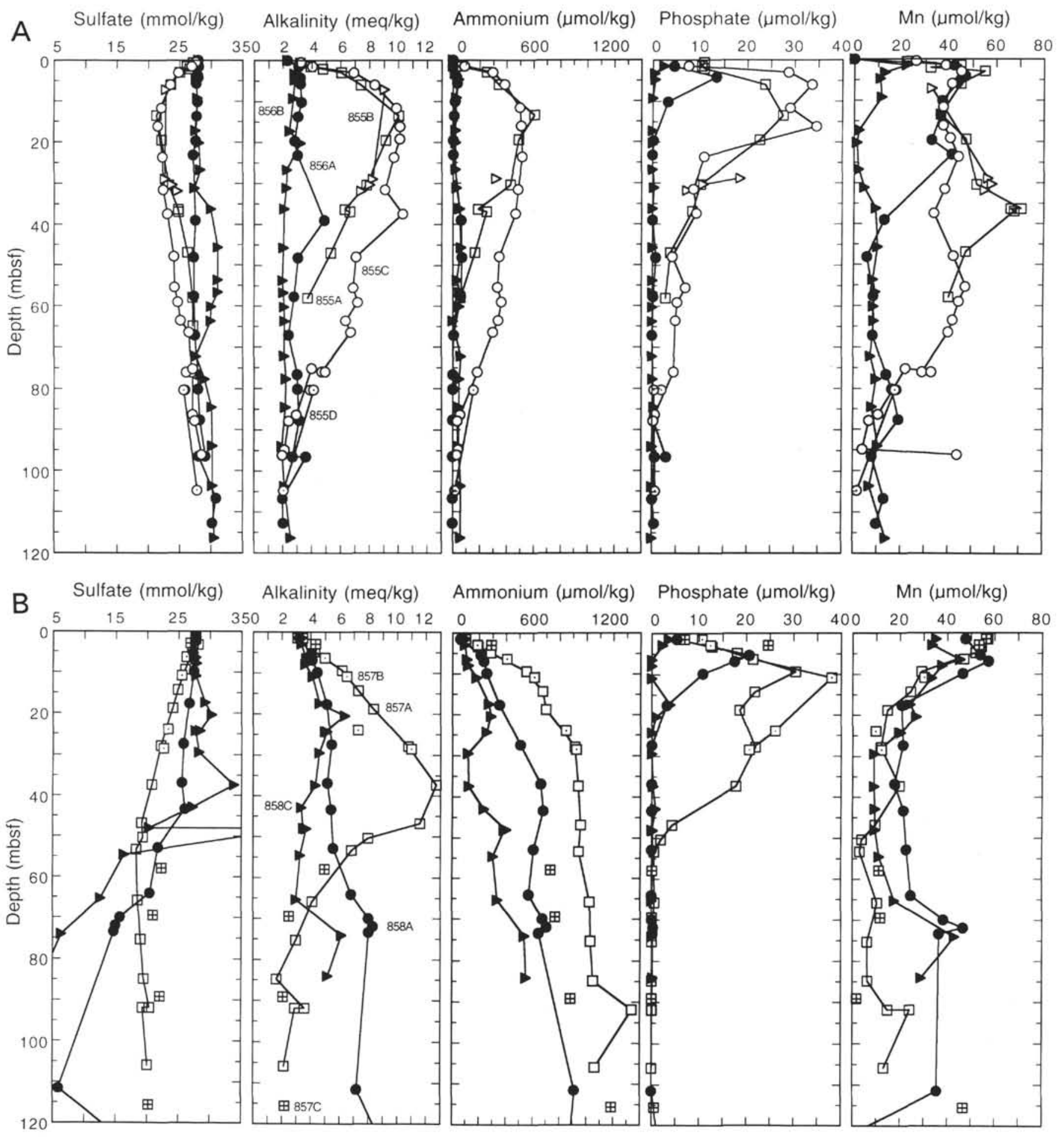

Figure 7. Composition of sediment pore waters from Sites 855 and 856 (A) and Sites 857 and 858 (B), upper 120 mbsf only.

crease greatly in the upper part of the sediment column at all sites except Site 856 (Fig. 7). Site 855, the coldest site, generally shows the largest changes in these five species within the upper $25 \mathrm{mbsf}$, which result mainly from bacterial oxidation of organic matter to bicarbonate, using sulfate as an oxidant and releasing ammonium and phosphate. The resulting reducing conditions mobilize manganese. Of the four sites, sediment at Site 855 has among the highest concentrations of total organic carbon (TOC) and nitrogen over this depth interval (Fig. 10), although the values are still low compared with most deep-sea sediment. At greater depths, these five species trend back toward their concentrations in seawater as basement is approached, due to the flow of unaltered seawater into basement at this site.

After Site 855 , Site 857 generally shows the next largest changes in these species, especially at 30 to $40 \mathrm{mbsf}$, where it has the lowest sulfate and highest alkalinity, ammonium, and phosphate. Its sediment has comparable TOC to Site 855 , although considerably less nitrogen, probably because of mobilization as dissolved ammonium, which is higher than at any other site. At greater depth sulfate in- 


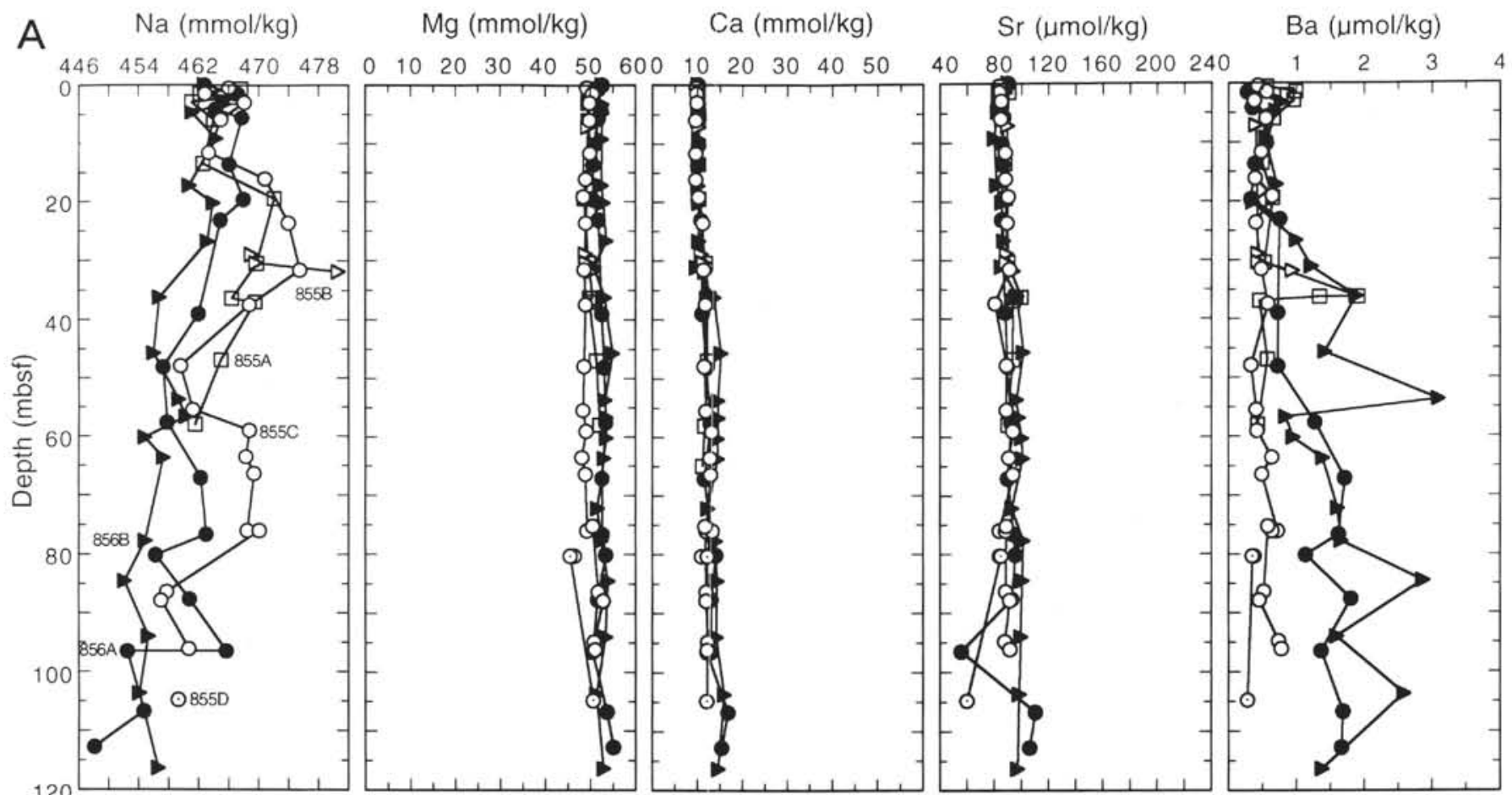

B

$\mathrm{Na}(\mathrm{mmol} / \mathrm{kg})$

$\mathrm{Mg}(\mathrm{mmol} / \mathrm{kg})$

$\mathrm{Ca}(\mathrm{mmol} / \mathrm{kg})$

$\mathrm{Sr}(\mu \mathrm{mol} / \mathrm{kg})$

$\mathrm{Ba}(\mu \mathrm{mol} / \mathrm{kg})$
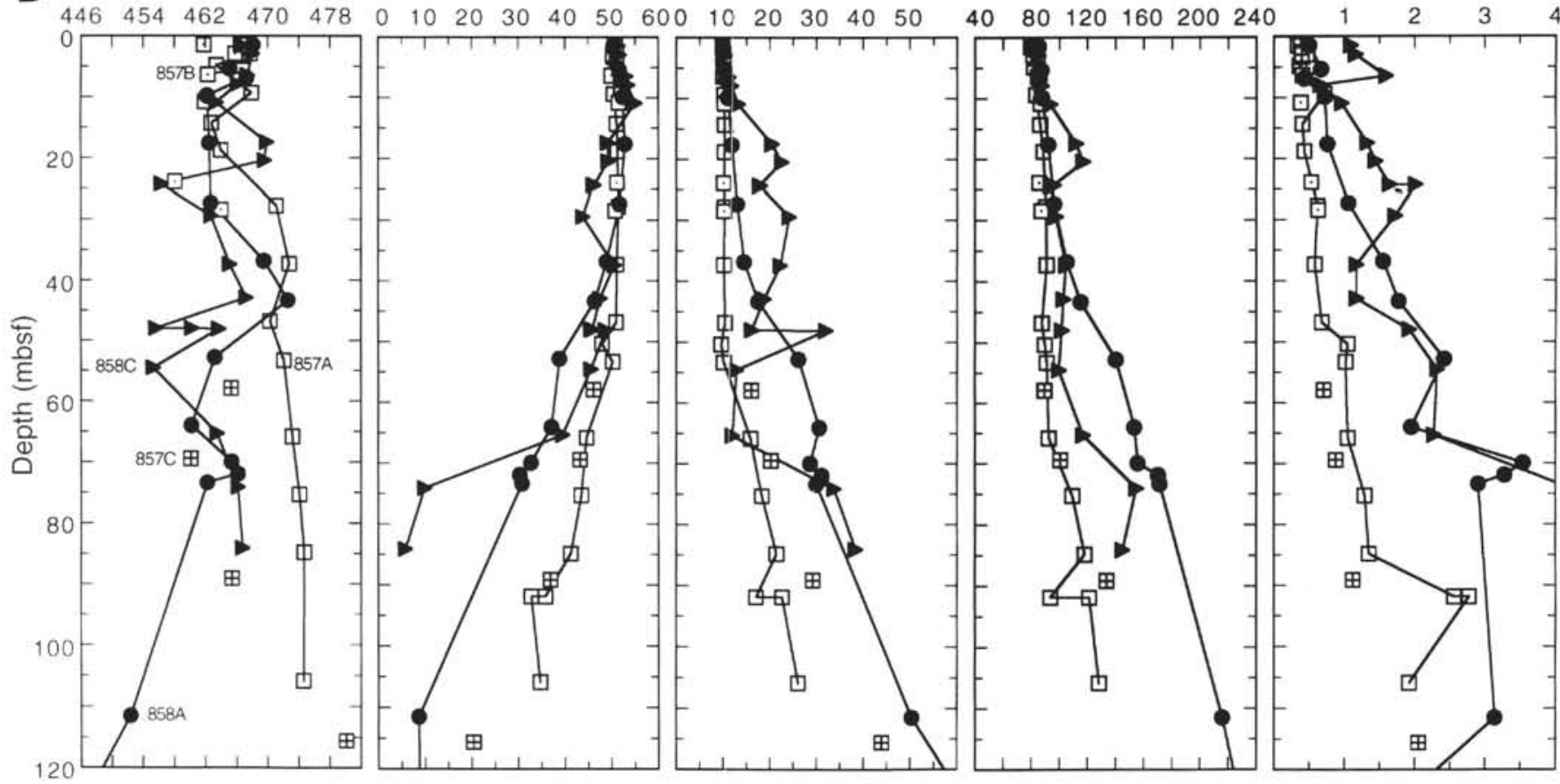

Figure 8. Composition of sediment pore waters from Sites 855 and $856(\mathbf{A})$ and Sites 857 and 858 (B), upper 120 mbsf only.

creases slightly toward its concentration in a zone of lateral flow between 115 and 145 mbsf, while alkalinity, phosphate, and manganese decrease. Ammonium, however, stays high. Cragg and Parkes (this volume) infer that bacteria continue to proliferate at Site 857 to about $120 \mathrm{mbsf}$, and persist but do not reproduce to $200 \mathrm{mbsf}$. At some depth in this range, therefore, as temperature increases, thermally induced reactions begin to dominate over bacterial reactions.

At the hottest Site 858, sulfate decreases with increasing depth and temperature except where anhydrite is redissolving in Hole $858 \mathrm{C}$.
Alkalinity, ammonium, and manganese exhibit a shallow maximum followed by a minimum and a subsequent increase to greater depth, either because of carbonate dissolution and increasing temperature, or because of lateral flow through the sediment, which is probably active in both Holes 858A and 858C (Shipboard Scientific Party, 1992). TOC and especially nitrogen are depleted in the sediment at this site, particularly in the hottest Hole $858 \mathrm{C}$ (Fig. 10).

Site 856 shows only a slight decrease in sulfate over the upper 25 mbsf and an increase at greater depth. TOC and nitrogen are depleted 

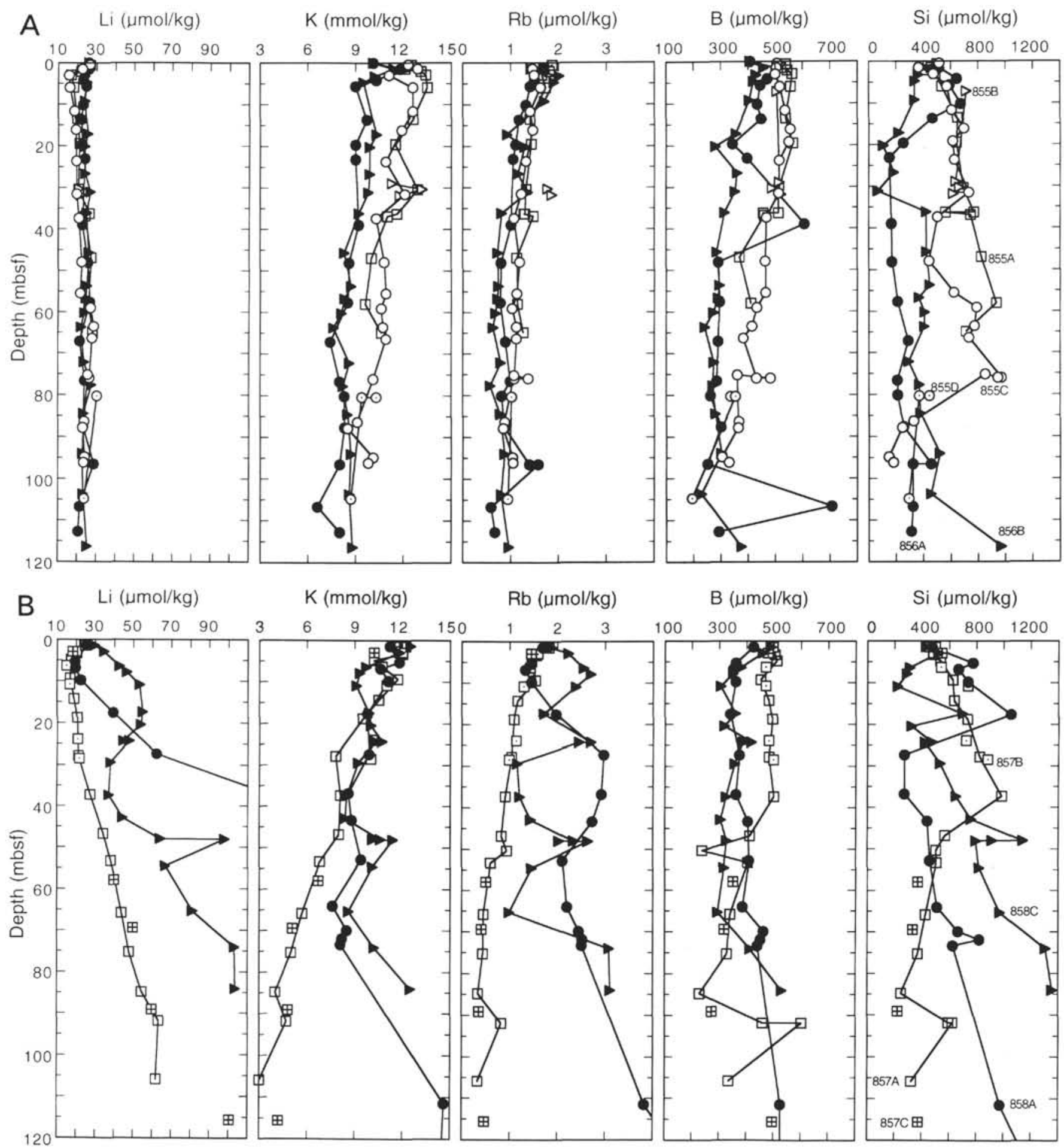

$\mathrm{Rb}(\mu \mathrm{mol} / \mathrm{kg})$

$\mathrm{B}(\mu \mathrm{mol} / \mathrm{kg})$

Si $(\mu \mathrm{mol} / \mathrm{kg})$

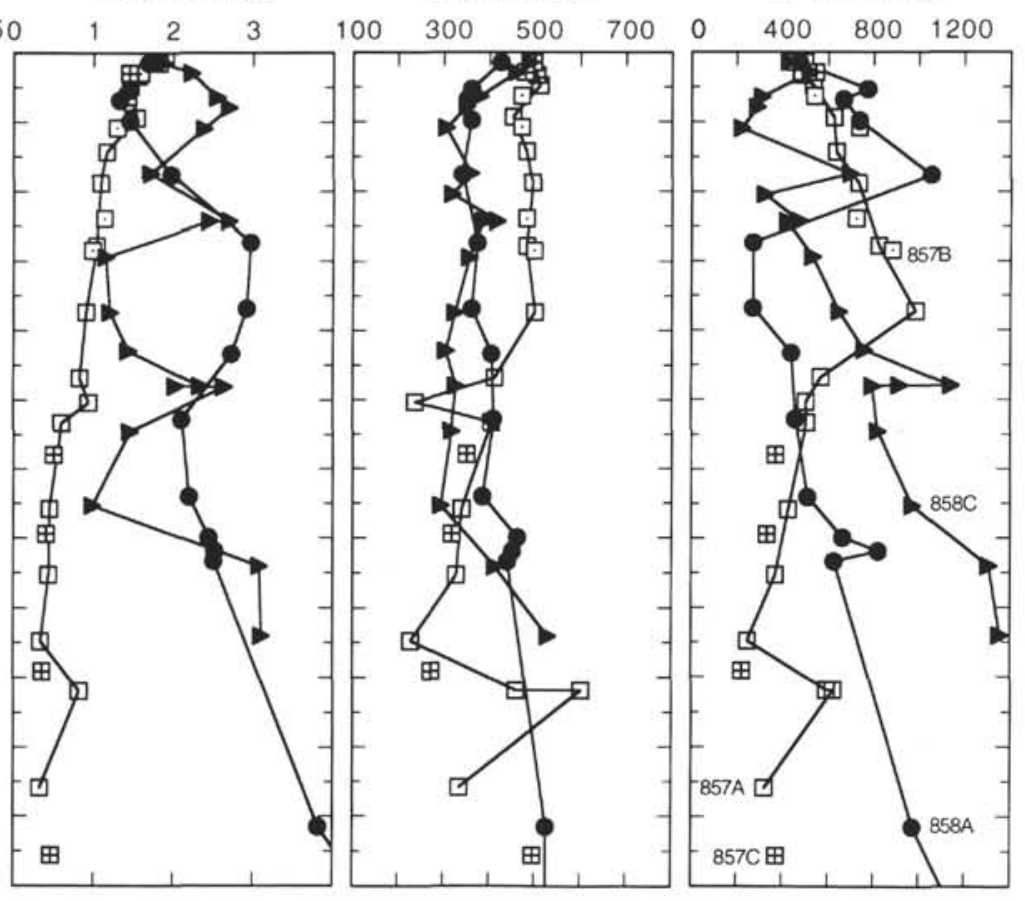

Figure 9. Composition of sediment pore waters from Sites 855 and 856 (A) and Sites 857 and 858 (B), upper 120 mbsf only.

in the sediment in Hole $856 \mathrm{~B}$, but in Hole $856 \mathrm{~A}$ their concentrations are comparable to the relatively high values at Site 855 , especially in the upper 25 mbsf. Given this comparison, it is surprising that the decrease in sulfate is so much smaller at Site 856 than at Site 855. One possible explanation for the difference is dissolution of anhydrite at Site 856 , which causes the increase in sulfate with depth below 48 mbsf in Hole 856A and $17 \mathrm{mbsf}$ in Hole 856B (Fig. 5). This explanation is unlikely, however, because the profiles for sulfate and calcium are nearly identical in the two holes to 17 mbsf, even though Hole
856B probably contains much more anhydrite (Table 2) and much less TOC than Hole $856 \mathrm{~A}$, especially in the upper $25 \mathrm{mbsf}$. A more likely explanation is that bacterial sulfate reduction has proceeded for only a brief period of time since the sediment column was flushed by Holocene bottom seawater. The minimal changes in alkalinity and ammonium at Site 856 compared with the other sites are consistent with this explanation.

Phosphate increases to a maximum in the surficial sediment at all four sites and then decreases to very low concentrations with depth. 
The depth at which phosphate approaches zero is shallowest for Hole $856 \mathrm{~B}$, followed by Holes $858 \mathrm{C}, 856 \mathrm{~A}, 858 \mathrm{~A}, 857 \mathrm{~A}-\mathrm{C}$, and $855 \mathrm{~A}-\mathrm{D}$. This is approximately the order of depletion of the sediment in TOC and nitrogen in these holes (Fig. 10). The depth at which phosphate approaches zero correlates with the depths of the shallow maxima in alkalinity and ammonium for all holes except Hole 856A. Phosphate goes to zero at present-day temperatures of $19^{\circ}$ to $42^{\circ} \mathrm{C}$ at Sites 857 and 858 , but at only $4^{\circ}$ to $10^{\circ} \mathrm{C}$ at Site 856 , consistent with the evidence that Site 856 was much hotter in the past.

Dissolved organic carbon at Site 856 is generally 2 to $6 \mathrm{mg} \mathrm{C} / \mathrm{L}$ and is lower in Hole 856B than in Hole 856A (Ran and Simoneit, this volume). Concentrations at the other three sites are almost always 7 $\mathrm{mg} \mathrm{C/L}$ or greater so that there is virtually no overlap with values from Site 856 . For this species, then, as for many others, the pore water at Site 856 resembles seawater more closely than does pore water at the other three sites.

One of the last major events inferred above for Site 856 is the slumping of about $21 \mathrm{~m}$ of sediment from the margin of Bent Hill at Hole 856B. This event must have occurred long enough in the past for profiles of dissolved sulfate, ammonium, and calcium to develop in the upper $17 \mathrm{~m}$ of sediment at Hole $856 \mathrm{~B}$ that closely resemble those at Hole $856 \mathrm{~A}$, which did not experience slumping. Alkalinity, phosphate, and manganese are lower at a given depth over this interval in Hole 856B than in Hole 856A, probably because of the lower TOC in Hole $856 \mathrm{~B}$. If the slumping accompanied sill intrusion, the uplift of Bent Hill, and flushing of the sediment column by seawater as suggested above, then the pore-water profiles at these two holes would have developed in parallel over the same period of time. This may be about the same length of time needed to dissipate the heat of intrusion of the sills, as is required by the absence of a thermal anomaly over Bent Hill. As noted above, Davis and Villinger (1992) suggested that a few thousand years would suffice to cool the sills.

\section{Sodium, Magnesium, Calcium, Strontium, and Barium}

These five elements generally behave similarly from site to site in sediment pore waters from Middle Valley. Relative to chlorinity, sodium typically decreases (Fig. 6), as does magnesium, whereas calcium, strontium, and barium increase (Fig. 8). Within the upper $120 \mathrm{mbsf}$ the site-to-site changes are correlated with temperature, being smallest at the coldest Site 855 and largest at the hottest Site 858 , with Site 857 intermediate. The only exceptions involve Site 856 . For sodium/chlorinity, calcium, and strontium, the warmer Hole $856 \mathrm{~B}$ shows a smaller change than the cooler Holes $857 \mathrm{~A}-\mathrm{C}$. For magnesium, Holes $856 \mathrm{~A}$ and $856 \mathrm{~B}$ are essentially unchanged from seawater, more so than at any other site. Only for barium does Hole $856 \mathrm{~B}$ show as large a change as at the cooler Site 857 , probably because barite is present in both Holes $856 \mathrm{~A}$ and $856 \mathrm{~B}$ (Table 3). All of these relationships are consistent with the shorter time of reaction between seawater and sediment hypothesized for Site 856, resulting from flushing of the sediment column by near-present-day bottom seawater, probably when the sills were intruded.

As was the case for sulfate, dissolved calcium and strontium increase near the sills in both Holes 856 A and 856B. In Hole 856A, calcium, strontium, and sulfate increase toward the sill at the bottom of the hole; in Hole 856B, they display a maximum near the sill at 62 mbsf, a minimum below that, and another increase toward the basal sill. This pattern can best be explained by ongoing dissolution of anhydrite that was deposited when the sills were intruded.

\section{Lithium, Potassium, Rubidium, Boron, and Silica}

Concentrations of these five species in hydrothermal solutions are typically strongly temperature dependent. Lithium, potassium, rubidium, and boron are taken up into solid phases at low temperature but leached into solution at high temperature (Mottl and Holland, 1978; Seyfried et al., 1984). All four elements show this behavior in pore waters from Middle Valley (Fig. 9). In addition, the profiles at the

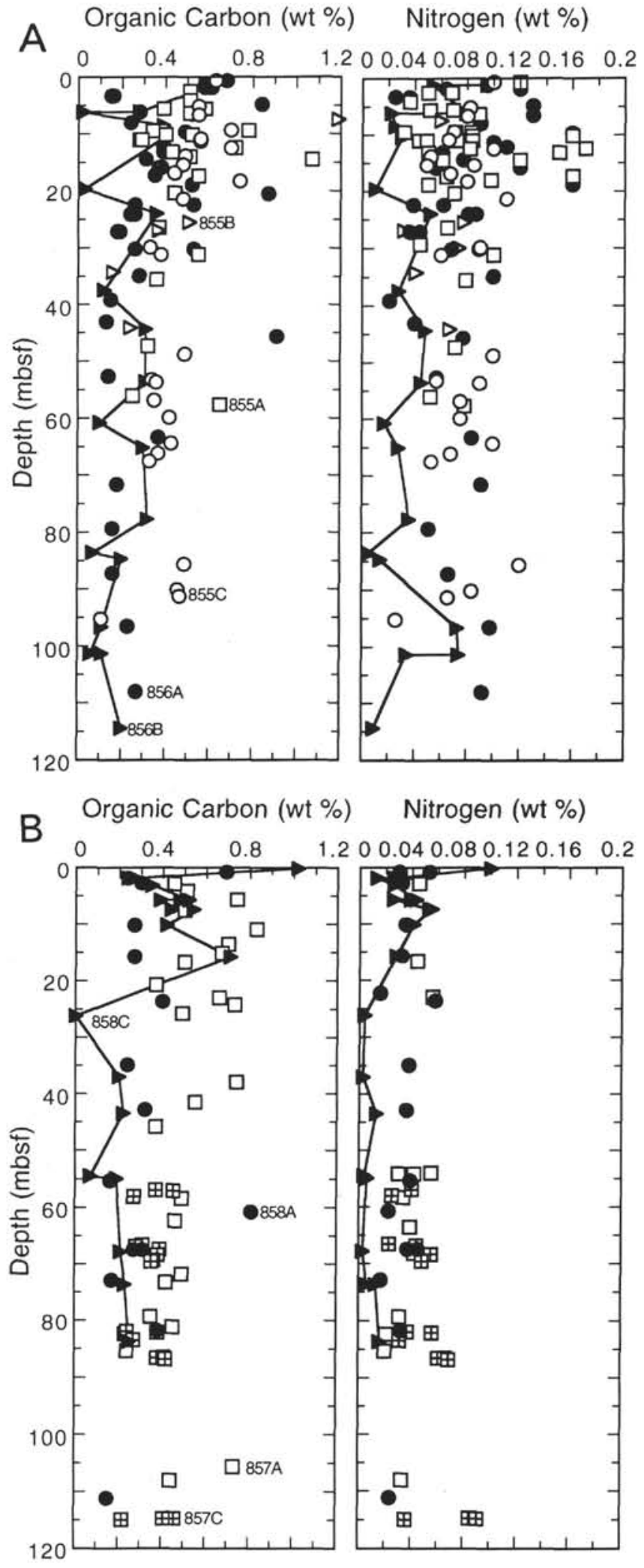

Figure 10. Composition of sediments from Sites 855 and $856(\mathbf{A})$ and Sites 857 and $858(\mathbf{B})$, upper $120 \mathrm{mbsf}$ only. 
hottest Site 858 show multiple maxima and minima that probably result from lateral flow.

Lithium increases with increasing temperature from Sites 855 to 857 to 858 , except for a decrease within the upper 3 to $7 \mathrm{mbsf}$, which is largest at the coldest Site 855. Site 856 is again anomalous, showing little or no change in lithium from the concentration in bottom seawater in spite of the moderately elevated temperatures there. Potassium and rubidium decrease with depth except at the hottest Site 858, where they begin to increase at shallow to intermediate depths. The coldest Site 855 is most similar to seawater, Site 856 is intermediate, and Site 857 shows the largest decrease.

Profiles of boron and silica are somewhat similar to one another. The hottest Site 858 has the highest concentrations, especially at greater depth. Sites 855 and 856 show increases at shallow depth and decreases at greater depth, to concentrations similar to those in bottom seawater for silica and below them for boron. Silica increases again near the bottom of Holes $856 \mathrm{~A}$ and $856 \mathrm{~B}$.

As for many other elements, Site 856 among all the sites shows the smallest change from seawater for lithium. For the other three species that are taken up at low temperature and leached at high temperature, namely potassium, rubidium, and boron, it is less obvious what a highly reacted solution would look like. Nevertheless, Holes $856 \mathrm{~A}$ and $856 \mathrm{~B}$ show very similar profiles, even though their temperature gradients straddle that at Site 857, which shows much larger changes. This suggests that pore waters from one or both of the holes at Site 856 have not reacted as far as they eventually would.

The nonreactive behavior of these elements at Site 856 is very different from that observed by Gieskes et al. (1982) at Deep Sea Drilling Project Sites 477, 478, and 481 in the Guaymas Basin, where large changes in lithium, potassium, and rubidium were found near sills. At Site 481, in particular, potassium decreases and rubidium increases greatly adjacent to a sill, while lithium increases to within $20 \mathrm{~m}$ above and below the sill but decreases abruptly as the sill is approached more closely. Carbonates just above this sill recrystallized at temperatures up to $170^{\circ} \mathrm{C}$, the same temperature range inferred for formation of carbonate nodules in Hole 856A (Fig. 4). Gieskes et al. (1982) attributed the general increase in lithium to leaching at high temperature, and the local decrease to subsequent uptake at lower temperature as the sill cooled. The contrast between these two sites implies that either the sills at Site 856 are older than that at Site 481 , or the sediment section at Site 481 was not flushed by bottom seawater as the sill cooled, as is inferred to have happened at Site 856. Given the evidence presented above that the sills at Site 856 are young, we prefer the latter explanation.

\section{CONCLUSIONS}

Whatever the relationship may be at other localities, it appears clear from drilling that at Site 856 , the large massive sulfide deposit is not genetically related to the adjacent circular hill called Bent Hill, for the following reasons:

1. Stratigraphic relationships, coupled with data on sedimentation rates, strongly suggest that the massive sulfide deposit had already begun to form by late in the Pleistocene, sometime between 140,000 and $220,000 \mathrm{yr}$ ago. This is the time required to accumulate the $18 \mathrm{~m}$ of interbedded hemipelagic and turbiditic sediments that overlie slumped beds of clastic massive sulfide in Hole 856B, $120 \mathrm{~m}$ north of the deposit, along with $20 \mathrm{~m}$ of similar sediment from the Pleistocene and less than $1 \mathrm{~m}$ of Holocene sediment that have slumped from the margin of Bent Hill at Hole 856B. The thickness of sediment lost by slumping is based on magnetostratigraphic correlation of Hole 856B with Hole 856A near the center of Bent Hill $190 \mathrm{~m}$ to the north. The sulfide deposit lacks hemipelagic or turbiditic interbeds and therefore either formed relatively quickly or remained highstanding throughout its history.
2. The top of the massive sulfide deposit is presently $3 \mathrm{~m}$ deeper than the seafloor at Hole $856 \mathrm{~B}$, even though up to $21 \mathrm{~m}$ of sediment may have slumped from Bent Hill at the site of Hole 856B. This indicates that either the deposit has sunk or the hill has risen since the clastic massive sulfide beds were deposited in Hole 856B. Given that the top of the deposit, which rises only $30 \mathrm{~m}$ above the surrounding seafloor, is devoid of sediment, whereas the adjacent 60 -m-high Bent Hill is covered by younger Pleistocene and Holocene sediment, it is much more likely that Bent Hill has risen since the clastic sulfide beds were deposited and, hence, since much or all of the massive sulfide body formed.

3. The temperature gradients at Site 856 were much higher in the past than they are at present. Much of the alteration exhibited by the sediments in Holes 856A and 856B doubtless occurred within the hydrothermal upflow zone that formed the massive sulfide deposit. There is abundant evidence for hydrothermal alteration as well, however, in the upper Pleistocene sediments that overlie the clastic sulfide beds in Hole 856B and in their correlatives in Hole 856A, including thermally mature hydrocarbons within the upper $10 \mathrm{mbsf}$ and anhydrite as shallow as 6 mbsf. This later alteration could be related to continued massive sulfide deposition, to the present-day hydrothermal venting at $265^{\circ} \mathrm{C} 460 \mathrm{~m}$ south of Hole $856 \mathrm{~B}$, or to intrusion of sills such as the three penetrated in Holes $856 \mathrm{~A}$ and $856 \mathrm{~B}$.

4. The sills in Holes $856 \mathrm{~A}$ and $856 \mathrm{~B}$ are picritic tholeiites that are more primitive than any other igneous rocks recovered from Middle Valley. They probably rose directly from the mantle and could not have provided the heat source for formation of the massive sulfide body.

5. There is no evidence that intrusion of these sills caused a substantial compaction of the intruded sediments, indicating that sills of this type could have been responsible for the uplift of Bent Hill.

6. The distribution of anhydrite and crystal molds after anhydrite in Holes 856A and 856B, coupled with the profiles of sulfate, calcium, and strontium in the sediment pore waters, strongly suggests that much anhydrite precipitated in response to intrusion of the sills. This anhydrite is presently redissolving.

7. The composition of sediment pore water in Holes $856 \mathrm{~A}$ and $856 \mathrm{~B}$ is markedly different from that at the other three Middle Valley sites over the same depth interval in that it is little changed from bottom seawater. This is the case for chlorinity, sulfate, alkalinity, ammonium, phosphate, manganese, magnesium, lithium, silica, and dissolved organic carbon. This similarity to seawater implies that the pore waters at Site 856 have reacted less with the sediment and basement than have pore waters at two other drill sites in Middle Valley, Sites 857 and 858 , even though the temperatures at Site 856 are higher than at the other two sites. The relatively unreacted pore water at Site 856 can best be explained by recent flushing of the sediment column by bottom seawater.

8 . The chlorinity profile at Site 856 , in particular, is nearly constant with depth at the value of present-day bottom seawater. As the chlorinity of bottom seawater has decreased from $560 \mathrm{mmol} / \mathrm{kg}$ at the height of the last glacial period $18,000 \mathrm{yr}$ ago to $540 \mathrm{mmol} / \mathrm{kg}$ today, the chlorinity profiles at Site 856 indicate that the sediment section there has been flushed with bottom seawater within the past few thousand years. The most likely cause of this flushing is intrusion of sills such as those penetrated in Holes 856A and 856B.

9. The slumping of about $21 \mathrm{~m}$ of Pleistocene and Holocene sediment from the margin of Bent Hill at Hole 856B occurred long enough ago for surficial profiles of dissolved sulfate, ammonium, and calcium to develop at Hole 856B that closely resemble those at Hole $856 \mathrm{~A}$, which did not experience slumping. If slumping accompanied intrusion of the sills, the uplift of Bent Hill, and flushing of the sediment column by seawater, then the pore-water profiles at these two holes would have developed in parallel over the same period of time.

10. This period of time may be about the same length as that needed to dissipate the heat of intrusion of the sills, as required by the absence of a thermal anomaly over Bent Hill. Davis and Villinger (1992) suggested that a few thousand years would suffice. 
We conclude, therefore, that Bent Hill was uplifted later than formation of much or all of the massive sulfide deposit. Whereas the deposit probably formed largely in the Pleistocene, and was already substantial by 140,000 to $220,000 \mathrm{yr}$ ago, Bent Hill was uplifted within the Holocene, probably within the last few thousand years.

\section{ACKNOWLEDGMENTS}

This work was supported by grants from the U.S. Science Support Program of the National Science Foundation. The paper benefited greatly from reviews by P.N. Froelich, J.M. Gieskes, and W. D. Goodfellow. This is contribution number 3532 from the School of Ocean and Earth Science and Technology of the University of Hawaii.

\section{REFERENCES}

Davis, E.E., Goodfellow, W.D., Bornhold, B.D., Adshead, J., Blaise, B., Villinger, H., and Le Cheminant, G.M., 1987. Massive sulfides in a sedimented rift valley, northern Juan de Fuca Ridge. Earth Planet. Sci. Lett., 82:49-61.

Davis, E.E., Mottl, M.J., Fisher, A.T., et al., 1992. Proc. ODP, Init. Repts., 139: College Station, TX (Ocean Drilling Program).

Davis, E.E., and Villinger, H., 1992. Tectonic and thermal structure of the Middle Valley sedimented rift, northern Juan de Fuca Ridge. In Davis, E.E., Mottl, M.J., Fisher, A.T., et al., Proc. ODP, Init. Repts., 139: College Station, TX (Ocean Drilling Program), 9-41.

Einsele, G., Gieskes, J. M., Curray, J., Moore, D. M., Aguago, E., Aubry, M.-P., Fornari, D., Guerrero, J., Kastner, M., Kelts, K., Lyle, M., Matoba, Y., Molina-Cruz, A., Niemitz, J., Rueda, J., Saunders, A., Schrader, H., Simoneit, B., and Vacquier, V., 1980. Intrusion of basaltic sills into highly porous sediments and resulting hydrothermal activity. Nature, 283:441-445.

Gieskes, J.M., Elderfield, H., Lawrence, J.R., Johnson, J., Meyers, B., and Campbell, A., 1982. Geochemistry of interstitial waters and sediments, Leg 64, Gulf of California. In Curray, J.R., Moore, D.G., et al., Init. Repts. DSDP, 64 (Pt. 2): Washington (U.S. Govt. Printing Office), 675-694.

Goodfellow, W.D., and Blaise, B., 1988. Sulphide formation and hydrothermal alteration of hemipelagic sediment in Middle Valley, northern Juan de Fuca Ridge. Can. Mineral., 26:675-696.

Goodfellow, W.D., and Franklin, J.M., in press. Geology, mineralogy and geochemistry of massive sulfides in shallow cores, Middle Valley, Northern Juan de Fuca Ridge. Econ. Geol.

Imbrie, J., Hays, J.D., Martinson, D.G., McIntyre, A., Mix, A.C., Morley, J.J., Pisias, N.G., Prell, W.L., and Shackleton, N.J., 1984. The orbital theory of Pleistocene climate: support from a revised chronology of the marine delta $\delta^{18} \mathrm{O}$ record. In Berger, A., Imbrie, J., Hays, J., Kukla, G., and Saltzman, B. (Eds.), Milankovitch and Climate (Pt. 1): Dordrecht (D. Reidel), 269305 .

Karsten, J., Hammond, S.R., Davis, E.E., and Currie, R.G., 1986. Detailed geomorphology of the Endeavour segment of the Juan de Fuca Ridge. Geol. Soc. Am. Bull., 97:213-221.

Lawver, L.A., and Williams, D., 1979. Heat flow in the central Gulf of California. J. Geophys. Res., 84:3465-3478.

Lonsdale, P., and Becker, K., 1985. Hydrothermal plumes, hot springs, and conductive heat flow in the southern trough of Guaymas Basin. Earth Planet. Sci. Lett., 73:211-225.

McDuff, R.E., 1985. The chemistry of interstitial waters, Deep Sea Drilling Project Leg 86. In Heath, G.R., Burckle, L.H., et al., Init. Repts. DSDP, 86: Washington (U.S. Govt. Printing Office), 675-687.

Morton, J.L., Holmes, M.L., and Koski, R.A., 1987. Volcanism and massive sulfide formation at a sedimented spreading center, Escanaba Trough, Gorda Ridge, northeast Pacific Ocean. Geophys. Res. Lett., 14:769-772.

Mottl, M.J., and Holland, H.D., 1978. Chemical exchange during hydrothermal alteration of basalt by seawater. I. Experimental results for major and minor components of seawater. Geochim. Cosmochim. Acta, 42:11031115.

Seyfried, W.E., Janecky, D.R., and Mottl, M.J., 1984. Alteration of oceanic crust: implications for geochemical cycles of lithium and boron. Geochim Cosmochim. Acta, 48:557-569.

Seyfried, W.E., Jr., and Bischoff, J.L., 1979. Low temperature basalt alteration by seawater: an experimental study at $70^{\circ} \mathrm{C}$ and $150^{\circ} \mathrm{C}$. Geochim. Cosmochim. Acta, 43:1937-1947.

Shipboard Scientific Party, 1992. Site 856. In Davis, E.E., Mottl, M.J., Fisher A.T., et al., Proc. ODP, Init. Repts., 139: College Station, TX (Ocean Drilling Program), 161-281.

Zierenberg, R.A., Morton, J.L., Koski, R.A., and Ross, S.L., in press. Geologic setting of massive sulfide mineralization in Escanaba Trough. In Morton, J.L., Zierenberg, R., and Reiss, C.A. (Eds.), Geologic, Hydrothermal, and Biological Studies at Escanaba Trough, Gorda Ridge, Offshore California. U.S. Geol. Surv. Bull., 2022.

\footnotetext{
Abbreviations for names of organizations and publications in ODP reference lists follow the style given in Chemical Abstracts Service Source Index (published by American Chemical Society),
}

Date of initial receipt: 17 June 1993

Date of acceptance: 30 September 1993

Ms 139SR-232 